\title{
Ensemble and Single-Molecule Biophysical Characterization of D17.4 DNA Aptamer-IgE Interactions
}

Mohan-Vivekanandan Poongavanam ${ }^{\mathrm{a}}$, Lydia Kisley ${ }^{\mathrm{b}}$, Katerina Kourentzi ${ }^{\mathrm{c}}$, Christy F. Landes ${ }^{\mathrm{b}, \mathrm{d} *}$, Richard C. Willson ${ }^{\mathrm{a}, \mathrm{c}, \mathrm{e}, \mathrm{f} \star}$

${ }^{a}$ Department of Biology and Biochemistry, University of Houston, TX, 77204-4004, USA

${ }^{\mathrm{b}}$ Department of Chemistry, Rice University, Houston, TX, 77251-1892, USA

${ }^{c}$ Department of Chemical and Biomolecular Engineering, University of Houston, TX, 772044004, USA

${ }^{\mathrm{d}}$ Department of Electrical and Computer Engineering, Rice University, Houston, TX, 770051827, USA

${ }^{\mathrm{e}}$ Houston Methodist Research Institute, Houston, TX, 77204-4004, USA

${ }^{\mathrm{f}}$ Centro de Biotecnología FEMSA, Departamento de Biotecnología e Ingeniería de Alimentos, Tecnológico de Monterrey, Monterrey, 64849, Mexico

*Corresponding authors:

Dr. Richard C. Willson, University of Houston, Department of Chemical and Biomolecular Engineering, 4800 Calhoun Rd., Houston, TX 77204-4004, USA.

Phone: +1 (713) 743-4308; Fax: +1 (713) 743-4323; e-mail: willson@uh.edu

Dr. Christy F. Landes, Rice University, Department of Chemistry, Space Science 201, Houston, TX, 77251-1892, USA.

Phone: +1 (713) 348-4232; Fax: +1 (713) 348-5155; e-mail: cflandes@ rice.edu 


\begin{abstract}
Background: The IgE-binding DNA aptamer 17.4 is known to inhibit the interaction of IgE with the high-affinity IgE Fc receptor FceRI. While this and other aptamers have been widely used and studied, there has been relatively little investigation of the kinetics and energetics of their interactions with their targets, by either single-molecule or ensemble methods.

Methods: The dissociation kinetics of the D17.4/IgE complex and the effects of temperature and ionic strength were studied using fluorescence anisotropy and single-molecule spectroscopy, and activation parameters calculated.

Results: The dissociation of D17.4/IgE complex showed a strong dependence on temperature and salt concentration. The $\mathrm{k}_{\text {off }}$ of D17.4/IgE complex was calculated to be $(2.92 \pm 0.18) \times 10^{-3} \mathrm{~s}^{-1}$ at 50 $\mathrm{mM} \mathrm{NaCl}$, and $(1.44 \pm 0.02) \times 10^{-2} \mathrm{~s}^{-1}$ at $300 \mathrm{mM} \mathrm{NaCl}$, both in $1 \mathrm{mM} \mathrm{MgCl} 2$ and $25{ }^{\circ} \mathrm{C}$. The dissociation activation energy for the D17.4/IgE complex, $\mathrm{E}_{\mathrm{a}}$, was $16.0 \pm 1.9 \mathrm{kcal} \mathrm{mol}^{-1}$ at $50 \mathrm{mM}$ $\mathrm{NaCl}$ and $1 \mathrm{mM} \mathrm{MgCl}$. Interestingly, we found that the C19A mutant of D17.4 with stabilized stem structure showed slower dissociation kinetics compared to D17.4. Single-molecule observations of surface-immobilized D17.4/IgE showed much faster dissociation kinetics, and heterogeneity not observable by ensemble techniques.

Conclusions: The increasing $\mathrm{k}_{\text {off }}$ value with increasing salt concentration is attributed to the electrostatic interactions between $\mathrm{D} 17.4 / \mathrm{IgE}$. We found that both the changes in activation enthalpy and activation entropy are insignificant with increasing $\mathrm{NaCl}$ concentration. The slower dissociation of the mutant $\mathrm{C} 19 \mathrm{~A} / \mathrm{IgE}$ complex is likely due to the enhanced stability of the aptamer.
\end{abstract}


General significance: The activation parameters obtained by applying transition state analysis to kinetic data can provide details on mechanisms of molecular recognition and have applications in drug design. Single-molecule dissociation kinetics showed greater kinetic complexity than was observed in the ensemble in-solution systems, potentially reflecting conformational heterogeneity of the aptamer.

Keywords: Aptamer, molecular recognition, fluorescence anisotropy, dissociation kinetics, electrostatic interactions, and activation parameters.

\section{Introduction}

Aptamers are library-selected single-stranded oligonucleotide (DNA or RNA) ligands that fold into three-dimensional structures and are capable of binding to pre-selected targets. Aptamers usually are selected using SELEX (Systematic Evolution of Ligands by EXponential enrichment), an in vitro process involving iterative binding, elution, and PCR amplification [1, 2], which allows isolation of target-specific DNA or RNA molecules from a large pool $\left(\sim 10^{15}\right)$ of random oligonucleotides. The first aptamer-based therapeutic for wet, age-related macular degeneration was approved by FDA in 2005 [3] and aptamers for treating various other diseases (e.g., acute coronary syndrome, von Willebrand factor related disorders, angiomas, acute myeloid leukemia) are currently in clinical trials [4] with two of them in phase 3 [5]. The antithrombin aptamer [6] that acts as an anti-coagulant agent has been used as a short-term anticoagulant designed for the application in the coronary artery bypass graft surgery and its optimized form is under phase 2 clinical trials with the added advantage that complimentary

oligonucleotides efficiently reverse the activity of the aptamer providing a method for regulating the action of the therapeutic [7]. Apart for therapeutics, aptamers are being considered for a wide range of other applications including diagnostics, forensics, and biodefense [8-10]. 
IgE has been demonstrated to play a major role in mammalian immune defense by eliciting protective responses including local inflammation, itching, and mucus production [11]. A crucial step in these responses is the binding of $\operatorname{IgE}$ antibodies to the $\operatorname{IgE} F c$ receptor (FceRI), found primarily on mast cells and basophils [12]. One promising approach to treatment of IgEmediated diseases is to block IgE/FceRI interactions [13, 14]. Omalizumab, an FDA-approved humanized anti-IgE monoclonal antibody that targets and binds to circulating free $\operatorname{IgE}$ and prevents the interaction of $\mathrm{IgE}$ with the Fc\&RI receptor, is used for treating severe persistent allergic asthma including manifestations of exposure to peanuts in patients with peanut allergy [15]. Wiegand and co-workers [12] reported a SELEX-isolated IgE-binding DNA aptamer, D17.4, that was shown to inhibit the binding of IgE to FceRI. The binding site of D17.4 is reported to be identical with or at least in close proximity to the $\mathrm{C} \varepsilon 3$ region contact point of $\operatorname{IgE}$ with FceRI [12]. The D17.4 aptamer has been extensively studied, and found to have a lownanomolar affinity for IgE by various methodologies (10 $\mathrm{nM}$ using filter binding [12], 15 $\pm 4 \mathrm{nM}$ using fluorescence anisotropy [16], $8 \mathrm{nM}$ using capillary electrophoresis [17]). The D17.4 aptamer has been used as a recognition element in biosensing for sensitive IgE detection [18-23]. The mfold-predicted [24] stem-loop structure of D17.4 at $\left[\mathrm{Na}^{+}\right]=138 \mathrm{mM},\left[\mathrm{Mg}^{2+}\right]=1 \mathrm{mM}$ and $25^{\circ} \mathrm{C}$ is shown in Fig. 1.

Most prior work on aptamer/protein interactions has focused on characterizing binding affinity, identifying residues involved in aptamer recognition, and application of aptamers in therapeutics $[4,25]$ and biosensing [18-21]; relatively little is known about the kinetics and energetics of aptamer/protein interactions. In this work we studied the dissociation kinetics, the effects of temperature and ionic strength, and the kinetic activation parameters of the D17.4 
aptamer/IgE complex using fluorescence anisotropy [26-30]. From the dissociation kinetic data at various temperatures we calculated the dissociation activation energy $\left(\mathrm{E}_{\mathrm{a}}\right)$, activation enthalpy $\left(\Delta H^{\#}\right)$, and activation entropy $\left(\Delta S^{\#}\right)$ for the D17.4 aptamer/IgE complex. The role of specific structural features of the D17.4 aptamer was investigated using single-nucleotide mutations.

The study of dynamic biological events at the nanoscale has been greatly advanced in recent years by the advent of single molecule spectroscopy (SMS). Recent advances in SMS have made it possible to discern individual dynamical events within complex biological processes such as binding [31-34] and structural fluctuations [35-38]. Single molecule imaging by Total Internal Reflectance Fluorescence (TIRF) microscopy and fluorescence resonance energy transfer are useful in measuring single association/dissociation events without the ensemble averaging that occurs in bulk measurements [39-44]. By measuring time-dependent signals over large areas, it is possible to extract equilibrium and non-equilibrium kinetic values for many molecules in parallel, directly from single molecule dwell time analysis, and characterize distributions of functionality and behavior (e.g. aptamers $[45,46])$. Here we use SMS to observe the heterogeneity of the dissociation kinetics of IgE from the D17.4 aptamer under variable ionic strength. 


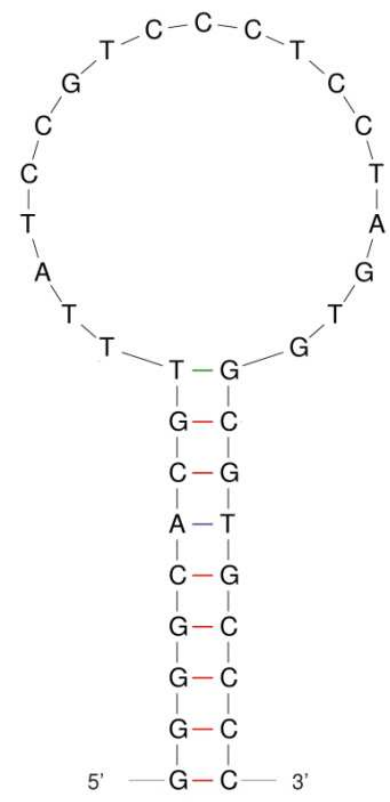

(A)

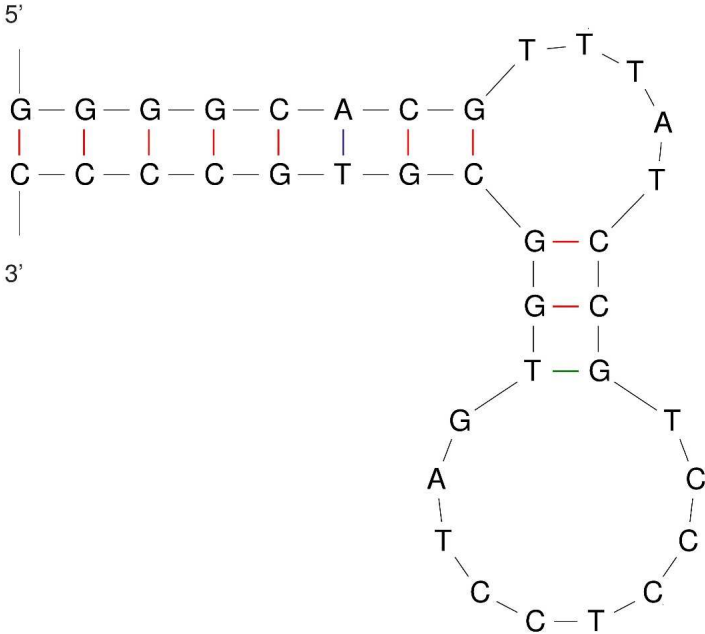

(B)

Fig. 1. Mfold-predicted secondary structure of D17.4 aptamer; (A) at $\left[\mathrm{Na}^{+}\right]=138 \mathrm{mM},\left[\mathrm{Mg}^{2+}\right]=$ $1 \mathrm{mM}$ and $25^{\circ} \mathrm{C}, \Delta \mathrm{G}=-9.93 \mathrm{kcal} / \mathrm{mol}$; predicted secondary structure remains the same at $\left[\mathrm{Na}^{+}\right]=$ $50 \mathrm{mM}(\Delta \mathrm{G}=-9.53 \mathrm{kcal} / \mathrm{mol})$ or $200 \mathrm{mM}(\Delta \mathrm{G}=-10.15 \mathrm{kcal} / \mathrm{mol})$ and $\left[\mathrm{Mg}^{2+}\right]=1 \mathrm{mM}$. (B) at $\left[\mathrm{Na}^{+}\right]=300 \mathrm{mM},\left[\mathrm{Mg}^{2+}\right]=1 \mathrm{mM}$ and $25^{\circ} \mathrm{C}, \Delta \mathrm{G}=-9.40 \mathrm{kcal} / \mathrm{mol}$.

\section{Materials and methods}

\section{$2.1 \quad$ Reagents}

The 37-mer IgE-binding aptamer (D17.4), with the sequence 5'GGGGCACGTTTATCCGTCCCTCCTAGTGGCGTGCCCC-3', was used as reported in the literature [12]. HPLC-purified (unlabeled, 5'-labeled with Texas Red and 3'-modified with biotin (separated from the DNA sequence with a $\mathrm{T}_{15}$ spacer) with or without a 5'-Cy5 fluorophore) D17.4 aptamer was purchased from Integrated DNA Technologies (IDT, Coralville, IA, USA). Texas Red-labeled mutant aptamers bearing a single-nucleotide change in the original D17.4 sequence, D17.4-G1T (G at position 1 was replaced with T), D17.4-C19A and D17.4-C19G, also were from IDT. Human IgE protein (from plasma) was purchased from Athens Research and 
Technology Inc. (Athens, GA, USA; 16-16-090705-M) and used without further purification. Vectabond (aminosilane; SP1800) was purchased from Vector Laboratories (Burlingame, CA, USA). Methoxy-PEG-NHS (MW: 5,000; 85969-1G) and biotin-PEG-NHS (MW: 5,000; BI050TS) were purchased from Sigma-Aldrich (St. Louis, MO, USA) and NOF America Corporation (White Plains, NY, USA) respectively. Streptavidin (S888) was purchased from Life Technologies (Carlsbad, CA, USA). All other reagents were purchased from Sigma-Aldrich). Ultra-pure water (conductivity $\geq 18 \mathrm{~m} \Omega$ ) from a Millipore water purification system was used in all experiments.

\subsection{Instrumentation and ensemble data acquisition}

An OLIS DM 45 fluorometer was used for fluorescence anisotropy measurements. Planepolarized light exiting from the excitation polarizer (set in the vertical position) passes through the photoelastic modulator (PEM-90) operating at half-wave retardation before passing through the sample cuvette. The PEM modulator, installed with its axis at $45^{\circ}$ from the polarizer direction, generates excitation light with vertical and horizontal polarizations alternating at a frequency of $100 \mathrm{kHz}$. The emitted light is detected at a right angle to the excitation axis by a photomultiplier tube detector (without the use of any polarizer in front of the detector). The parallel and perpendicular data are digitized from the raw PMT signals. The signal identity ( $I_{I I}$ parallel or $I_{\perp}$ perpendicular) is known from the synchronization signal from the PEM. Signals ( $I_{I I}$ parallel or $I_{\perp}$ perpendicular) are accumulated in two channels based on the position in the cycle. Anisotropy values (r; Equation 1) are calculated automatically within the instrument software [47-49].

$$
r=\frac{I_{I I}-I_{\perp}}{I_{I I}+2 I_{\perp}}
$$




\subsection{Dissociation kinetics and data analysis}

Experiments were performed in binding buffer matching the previously reported SELEX selection conditions: $8.1 \mathrm{mM} \mathrm{Na}_{2} \mathrm{HPO}_{4}, 1.1 \mathrm{mM} \mathrm{KH}_{2} \mathrm{PO}_{4}, 1 \mathrm{mM} \mathrm{MgCl} 2,2.7 \mathrm{mM} \mathrm{KCl}$, and 138 $\mathrm{mM} \mathrm{NaCl}, \mathrm{pH}$ adjusted to 7.4 [12]. Proper folding was ensured by heating the aptamer at $90^{\circ} \mathrm{C}$ for 3 min and then slowly cooling it to room temperature prior to each set of experiments. A 100$\mu \mathrm{L}$ quartz cuvette (StarnaCells, Atascadero, CA, USA) with a 10-mm path length was used in all dissociation experiments. Based on earlier reported observations [16], we used Texas Redlabeled D17.4 aptamer since this dye was found to be more suitable for reporting D17.4 aptamer motion than the more commonly used fluorescein. The dissociation was initiated by the addition of excess (50-fold, unless otherwise specified) unlabeled (original or mutant) aptamer to preformed (20 min incubation) Texas Red-labeled (wild or mutant type) aptamer:IgE (1:8) complexes. The final volume after titration was less than 1.1 times the initial volume and thus dilution was negligible. We observed minimal quenching (6.9\%) of the total fluorescence of the aptamer upon addition of protein and this quenching effect was neglected in kinetic data analysis. In separate experiments, it was determined that the anisotropy of unperturbed complexes remained constant for the duration of the experiment ( 1800 s). Experiments in which the age of the complex was varied (from 20 to $60 \mathrm{~min}$ ) prior to inducing dissociation affected neither the observed off rate nor the single-exponential nature of the data. For the data analysis, the raw anisotropy data were bin averaged $\left(\sim 58 \mathrm{~s}\right.$ for $300 \mathrm{mM} \mathrm{NaCl}, 30^{\circ} \mathrm{C}$ and $\sim 151 \mathrm{~s}$ for 50 $\left.\mathrm{mM} \mathrm{NaCl}, 10^{\circ} \mathrm{C}\right)$, normalized using Equation 2 and plotted as fraction of aptamer bound $\left(f_{b}\right)$ versus time (t) elapsed since the addition of unlabeled competitor aptamer.

$$
f_{b}(t)=\frac{A(t)-A_{f}}{A_{b}-A_{f}}
$$


where $A(t)$ is the measured anisotropy of the sample at time $\mathrm{t}, A_{f}$ is the anisotropy of the free aptamer and $A_{b}$ is the anisotropy of the complex just before dissociation. A first-order, singleexponential model (Equation 3) was found to describe the dissociation data better than alternative models:

$$
f_{b}(t)=y_{0}+y e^{-k o f f * t}
$$

where $f_{b}(t)$ is the fraction of aptamer bound at time t elapsed since the addition of unlabeled competitor aptamer, $\mathrm{k}_{\mathrm{off}}$ is the observed dissociation rate constant $\left(\mathrm{s}^{-1}\right), \mathrm{y}+\mathrm{y}_{0}$ is the fraction of aptamer bound just prior to induction of dissociation and $\mathrm{y}_{0}$ is the residual fraction of aptamer bound after very long dissociation time $(\mathrm{t} \rightarrow \infty)$. Data fitting was performed using the nonlinear least squares regression algorithms implemented in Igor Pro 6.05 (WaveMetrics, Lake Oswego, OR, USA). The dissociation experiments were performed to near completion as indicated by the fact the anisotropy at the end of the monitored dissociation time approached that of the free aptamer, and the calculated fraction of aptamer remaining bound $\left(\mathrm{y}_{\mathrm{o}}\right)$ was less than $7 \%$.

\subsection{Calculation of transition-state thermodynamic parameters}

The temperature dependence of the reaction rate was fit by the Arrhenius equation [27, 28] as follows:

$$
\ln \left(k_{o f f}\right)=\frac{-E_{a}}{R T}+\ln A
$$

where $\mathrm{k}_{\text {off }}$ is the dissociation rate constant $\left(\mathrm{s}^{-1}\right), \mathrm{T}$ is the absolute temperature, $\mathrm{R}$ is the gas constant $\left(1.98 \mathrm{cal} \mathrm{K}^{-1} \mathrm{~mol}^{-1}\right)$ and $\mathrm{A}$ is the collision frequency factor. The activation energy is calculated from the slope $\left(\frac{-E_{a}}{R}\right)$ of a plot of $\ln \left(\mathrm{k}_{\mathrm{off}}\right) v s .1 / T$ using the LINEST function in Microsoft Office Excel. The activation parameters, enthalpy change of activation, $\Delta H^{\#}$ (the 
superscript symbol denotes the transition state with all components in their standard state, $\mathrm{T}=$ $298 \mathrm{~K})$, entropy change of activation, $\Delta S^{\#}$ and free energy change of activation, $\Delta G^{\#}$ were calculated from the following equations:

$\Delta H^{\#}=E_{a}-R T$

$\Delta S^{\#}=R *\left(\ln \frac{A h}{k_{B} T}-1\right)$

$\Delta G^{\#}=\Delta H^{\#}-T \Delta S^{\#}$

where $\mathrm{h}$ is Planck's constant, $\mathrm{R}$ is the gas constant, and $\mathrm{k}_{\mathrm{B}}$ is the Boltzmann constant. The standard error (SE) for each activation parameter was estimated using error propagation from the standard error of the activation energy as calculated using the LINEST function.

\subsection{Sample preparation for single-molecule studies}

Standard glass coverslips ( 22 x 22 mm, No. 1; VWR, Houston, TX) were cleaned for $90 \mathrm{~s}$ in a basic TL1 solution (4\% (v/v) $\mathrm{H}_{2} \mathrm{O}_{2}$ and $\left.13 \%(\mathrm{v} / \mathrm{v}) \mathrm{NH}_{4} \mathrm{OH}\right)$ at $80 \square{ }^{\circ} \mathrm{C}$ and then with $\mathrm{O}_{2}$ plasma for 2 min at medium power (PDC-32G; Harrick Plasma, Ithaca, NY, USA) and finally functionalized with surface amine groups by immersion into Vectabond solution (2\% (v/v) in anhydrous acetone) for $5 \mathrm{~min}$. The coverslips were then placed into DI water for $30 \mathrm{~s}$ and then dried under a nitrogen stream. Custom silicon templates (Grace BioLabs, Bend, OR, USA) were placed on top of the cleaned cover slips and $35 \mu \mathrm{L}$ of a 100:1 mixture of methoxy-PEG-NHS $(25 \%(w / w)$ in water): biotin-PEG-NHS $(0.25 \%(w / w)$ in water), buffered with $0.84 \%(w / w)$ $\mathrm{NaHCO}_{3}$ were dispensed into the chamber and left (protected from light) to dry out overnight at room temperature. The chamber was then carefully removed and the coverslips were rinsed 
extensively with water and dried under a nitrogen stream. A custom flow chamber (1 mm height, with an elliptical opening of 12 × $5 \mathrm{~mm}$; 43018C, Grace BioLabs) was then placed over the modified area of the coverslip and streptavidin solution $(40 \mu \mathrm{l} ; 0.2 \mathrm{mg} / \mathrm{mL}$ in PBS) was added into the chamber and incubated (protected from light) for $10 \mathrm{~min}$. The flow chamber was then emptied and rinsed with $1 \mathrm{~mL}$ PBS. A 350 pM 3'-biotin-aptamer solution was denatured at $95^{\circ} \mathrm{C}$ and allowed to cool to room temperature to allow for proper folding. The aptamer solution was added into the chamber and incubated for $30 \mathrm{~min}$. The chamber was then rinsed with $1 \mathrm{mM}$ PBS and stored protected from light until used.

IgE was labeled with Cy3 succinimidyl ester (Lumiprobe Corp., Hallandale Beach, FL, USA; abs/em maxima 555/570 nm). The fluorophore was dissolved in dimethylformamide at a concentration of $10 \mathrm{mg} / \mathrm{mL}$, and $0.1 \mathrm{~mL}$ of this solution was slowly added to $100 \mu \mathrm{L}$ of $1 \mathrm{mg} / \mathrm{mL}$ IgE dissolved in PBS buffer, $\mathrm{pH} 7.4$, to preferentially label the protein amino termini rather than the lysine $\epsilon$-amino groups. The reaction was incubated at room temperature for $1 \mathrm{~h}$ with constant gentle mixing, and then stopped by addition of $0.1 \mathrm{~mL}$ of freshly prepared $1.5 \mathrm{M}$ hydroxylamine, $\mathrm{pH}$ 8.5. To remove any unincorporated fluorophores, Zeba spin desalting columns (Thermo Scientific) were used. The fluorophore-protein ratio was determined by absorbance readings at $555 \mathrm{~nm}$ and $280 \mathrm{~nm}$ to be 1.06 for the labeled $\mathrm{IgE}$.

A flow system (Genie Plus; Kent Scientific) was used to introduce Cy3-labeled IgE (2 $\mathrm{nM}$ in $\mathrm{PBS} / 200-400 \mathrm{mM} \mathrm{NaCl}$ ) into the chamber at $5 \mu \mathrm{L} / \mathrm{min}$ throughout the measurement. The low flow rate ensured negligible net force on the diffusion of the added IgE.

\subsection{Total Internal Reflectance Fluorescence (TIRF) Microscopy and data analysis}


A home-built total internal reflectance fluorescence microscope that has been described previously $[34,50]$ was used for fluorescence imaging. Briefly, the beam from a solid state 532 $\mathrm{nm}$ laser was used for excitation and passed through an acousto-optic modulator (AOM) controlled by frequency generators to synchronize excitation and detection rate enabling slower kinetics (otherwise masked by photobleaching of fluorophores) to be observable. When frames are being collected at the temporal limit of the detector, the laser is shut off between frames when data is not actually being collected (and only analog-to-digital signal conversion occurs) preventing unnecessary excitation of the fluorophores; this strategy extends the useful life of the fluorophores allowing for increased observation times [51]. In addition, variable collection frequency below the temporal limit of the detector is enabled by the amplitude-modulated excitation to enhance the ability to observe slow kinetics. By decreasing the collection frequency, decays from fast kinetics are lost, but decays from slow kinetics are observable that would otherwise be unobservable when using high collection frequency that leads to rapid fluorophore photobleaching. When varying the collection frequency $(1-16 \mathrm{~Hz})$ the low frequencies where data for slow kinetics converge are investigated and the appropriate frame collection frequency is then chosen. The modulated beam was expanded and focused at the edge of a 100x/1.45A-Plan-Fluar oil-immersion objective (Carl-Zeiss Microscopy LLC, Thornwood, NY, USA) for through-the-objective TIRF microscopy with a 1/e penetration depth of $\sim 85 \mathrm{~nm}$ and incident intensity of $\sim 5 \mathrm{~mW} / \mathrm{cm}^{2}$. Emission was collected back through the objective and was separated from excitation with a notch filter (HNPF-532.0-1.0, Kaiser Optical Systems, Ann Arbor, MI, USA) and a 585/65m bandpass filter. An EMCCD camera (iXon 897, Andor Technology, South Windsor, CT, USA) was used for detection at an integration time of $30 \mathrm{ms,}$ electron multiplying gain of 300 and variable frame collection rate $(1-16 \mathrm{~Hz})$ based on the 
amplitude modulation discussed above. Using TIRF microscopy, the labeled IgE molecules can be selectively observed only when adsorbed to the interface, and are made unobservable by motion blur when freely diffusing even near the interface due to their rapid diffusion [32]. Collected data was analyzed as described previously $[34,50]$.

\section{Results and Discussion}

3.1 Effect of salt $(\mathrm{NaCl})$ on aptamer-protein ensemble dissociation kinetics

The ensemble dissociation data was analyzed as described in section 2.3 and a singleexponential model was found to fit the data well, as judged by residual values and visual inspection of the corresponding semi-logarithmic plots (Fig. 2).

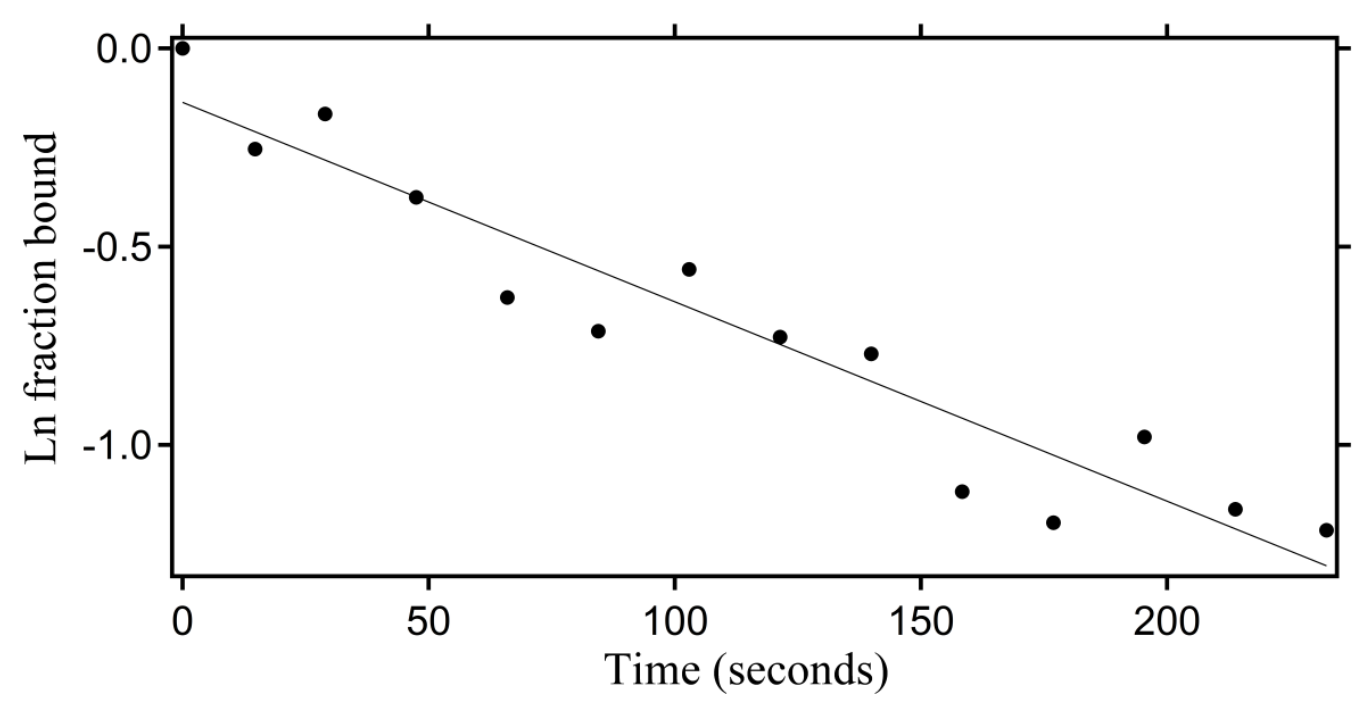

Fig. 2.Typical semi-log plot of labeled D17.4 aptamer bound to IgE vs. time. The linear nature of the plot implies single-exponential kinetics for the dissociation of Texas Red-labeled D17.4 aptamer $(40 \mathrm{nM})$ pre-complexed with $\mathrm{IgE}(320 \mathrm{nM})\left(8.1 \mathrm{mM} \mathrm{Na}_{2} \mathrm{HPO}_{4}, 1.1 \mathrm{mM} \mathrm{KH}_{2} \mathrm{PO}_{4}, 1 \mathrm{mM}\right.$ $\mathrm{MgCl}_{2}, 2.7 \mathrm{mM} \mathrm{KCl}$, and $138 \mathrm{mM} \mathrm{NaCl}, \mathrm{pH} 7.4$ at $25{ }^{\circ} \mathrm{C}$ ). Dissociation was performed with $2000 \mathrm{nM}$ unlabeled D17.4 aptamer.

The $\mathrm{k}_{\text {off }}$ of D17.4/IgE complex was calculated to be $(2.85 \pm 0.14) \times 10^{-3} \mathrm{~s}^{-1}$ at $138 \mathrm{mM}$ $\mathrm{NaCl}, 1 \mathrm{mM} \mathrm{MgCl} 2$ and $20{ }^{\circ} \mathrm{C}$. Our measured $\mathrm{k}_{\text {off }}$ value is in agreement with the previous reported $\mathrm{k}_{\mathrm{off}}=2.0 \times 10^{-3} \mathrm{~s}^{-1}$ measured using surface plasmon resonance (SPR) at $138 \mathrm{mM} \mathrm{NaCl}, 1$ 
$\mathrm{mM} \mathrm{MgCl}{ }_{2}$, and room temperature [52]. The small difference between our anisotropy results and the previous SPR results may be attributed to the effect on the $\mathrm{k}_{\mathrm{d}}$ of the D17.4 aptamer of adding a fluorescent dye, as reported previously [17] or of the solid phase necessarily present in SPR. Increasing the $\mathrm{NaCl}$ concentration from $50 \mathrm{mM}$ to $300 \mathrm{mM}$ (at $1 \mathrm{mM} \mathrm{MgCl}_{2}$ and $25^{\circ} \mathrm{C}$ ) resulted in a 5-fold increase in $\mathrm{k}_{\text {off }}$ from $(2.92 \pm 0.18) \times 10^{-3} \mathrm{~s}^{-1}$ at $50 \mathrm{mM} \mathrm{NaCl}$, to $(1.44 \pm 0.02) \times 10^{-2} \mathrm{~s}^{-1}$ at $300 \mathrm{mM} \mathrm{NaCl}$, both in $1 \mathrm{mM} \mathrm{MgCl} 2$ and $25{ }^{\circ} \mathrm{C}$. The increase in $\mathrm{k}_{\text {off }}$ with increasing salt concentration was observed at all temperatures studied $\left(10{ }^{\circ} \mathrm{C}, 20{ }^{\circ} \mathrm{C}, 25{ }^{\circ} \mathrm{C}\right.$ and $\left.30{ }^{\circ} \mathrm{C}\right)$ though the fold-increase over this range varied from 3 to 5 -fold in going from $50 \mathrm{mM}$ to $300 \mathrm{mM}$. It is notable that at $300 \mathrm{mM} \mathrm{NaCl}$ the mfold-predicted structure of the aptamer shows a two-loop conformation that it is different than the one predicted at lower ionic strength (Fig. 1). Wiegand et al. [12] reported based on a molecular model of the $\operatorname{IgE~Fc}$ domain, that a positively-charged patch in the ce3 domain was a possible binding site for D17.4 aptamer. The varying $\operatorname{IgE} \mathrm{pI}$ values reported in the literature $[(5.2-5.8)[10]$ and $(5.8-6.5)[53]]$ and the microheterogeneity in the isoelectric point of immunoglobulins have been attributed to a number of sources including variable glycosylation and de-amidation $[54,55]$. IgE has been reported [56] to have an overall negative charge at $\mathrm{pH}=7.4$. Dhaliwal et al. [57] reported a net overall positive $(+9)$ charge of the $\operatorname{IgE}$ ce3 domain, supporting the observation of Wiegand et al. [12]. We attribute the salt dependence of dissociation to the role of electrostatics in the interaction between the negatively charged phosphate backbone of DNA and the positive charge in the c $\varepsilon 3$ binding site for the D17.4 aptamer. Both aptamer-protein systems we characterized previously, an antilysozyme aptamer/lysozyme system and the aHt aptamer/vascular endothelial growth factor complex, also showed strong salt-dependent interaction, with $\mathrm{k}_{\mathrm{d}}$ decreasing at increasing $\mathrm{NaCl}$ concentration $[26,30]$. 
Fig. 3 shows a plot of $\log \mathrm{k}_{\text {off }} v s . \log [\mathrm{NaCl}]$ for the ensemble dissociation of D17.4/IgE complex at different temperatures. The salt effects on the dissociation rate constant for protein/DNA complex are described quantitatively by Lohman et al. [58] and are more complex than for the association rate constant since the major effect results from the need to re-condense cations on the DNA upon dissociation from the protein. In a buffer containing both monovalent $\left(\mathrm{Na}^{+}\right)$and polyvalent ions (e.g. $\mathrm{Mg}^{2+}$ ), as in the present studies, $\mathrm{Mg}^{2+}$ ions compete with $\mathrm{Na}^{+}$ions for binding to the nucleic acid and so the number of $\mathrm{Na}^{+}$ions re-condensed per phosphate is lower (than in a buffer containing only monovalent ions) and varies with both $\mathrm{Na}^{+}$and $\mathrm{Mg}^{2+}$ concentrations.

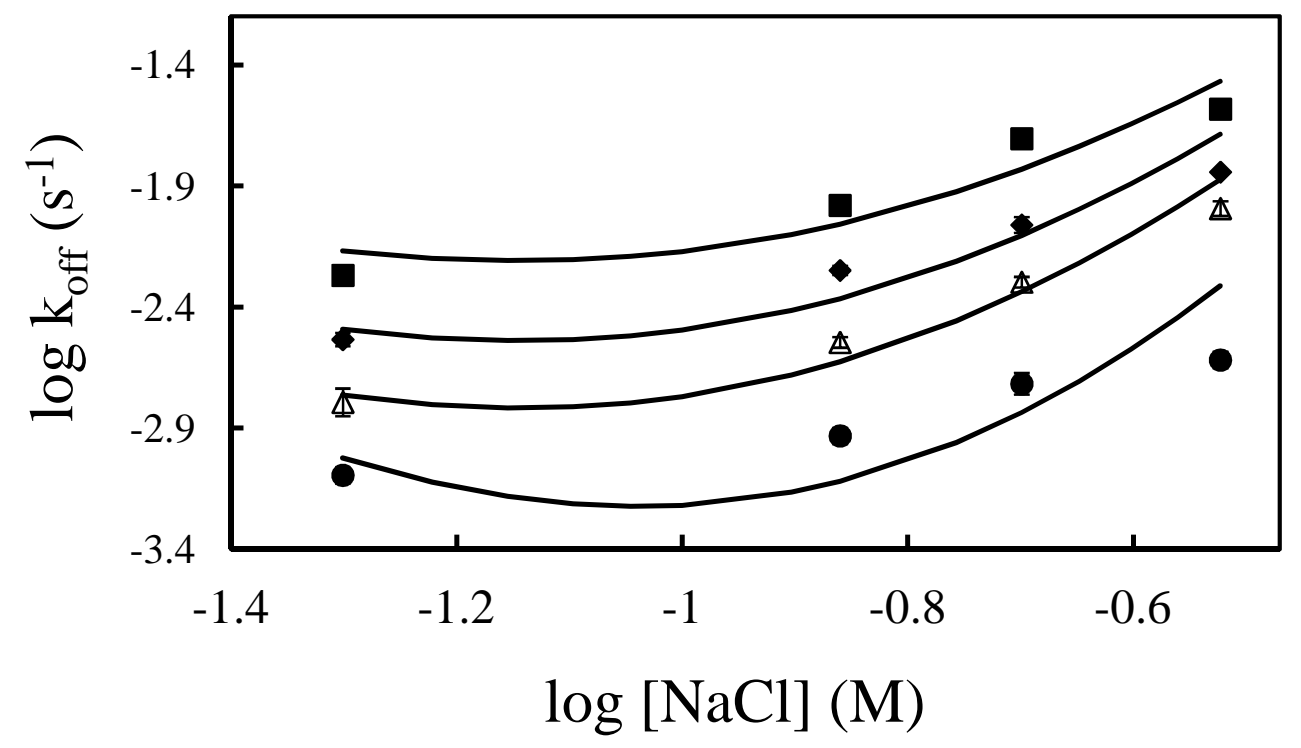

Fig. 3. Effect of $\mathrm{NaCl}$ on $\mathrm{D} 17.4 / \mathrm{IgE}$ dissociation kinetics. $\log \mathrm{k}_{\text {off }} v s$. $\log [\mathrm{NaCl}]$ plot showing salt dependence of $\mathrm{k}_{\text {off }}$ in a buffer containing $1 \mathrm{mM} \mathrm{MgCl}_{2}$ at different temperatures; $10{ }^{\circ} \mathrm{C}(\bullet)$, $20{ }^{\circ} \mathrm{C}(\Delta), 25{ }^{\circ} \mathrm{C}(\diamond)$ and $30{ }^{\circ} \mathrm{C}(\boldsymbol{\square})$. Curvature is due to the presence of $\mathrm{Mg}^{+2}$ as described in the text. Points are average $+/-$ Std Dev, $n=3$. The estimated $Z$ value was found to decrease with increasing temperature: $\mathrm{Z}=16$ at $10{ }^{\circ} \mathrm{C}, \mathrm{Z}=11$ at $20{ }^{\circ} \mathrm{C}, \mathrm{Z}=10$ at $25^{\circ} \mathrm{C}$ and $\mathrm{Z}=9$ at $30{ }^{\circ} \mathrm{C}$ and $\log K_{T}^{M g}$ was $\sim 1.5$.

Using the approach of Lohman et al. [58], the dependence of the $\log \mathrm{k}_{\text {off }}$ on the $\log$ of 
monovalent salt concentration in the buffer containing both monovalent and divalent ions is described by the following equation:

$\log k_{o f f}=Z \psi_{c} \log \left[M^{+}\right]+Z \log \left[1 / 2\left(1+\left(1+4 K_{o b s}^{M g}\left[M g^{2+}\right]\right)^{1 / 2}\right)\right]$

where $K_{o b s}^{M g}$ is the equilibrium constant for $\mathrm{Mg}^{2+}$ binding to the nucleic acid, $\mathrm{Z}$ represents the ionic charge contacts between cationic side chains and phosphate groups near the binding interface, and $\psi_{c}$ is the fraction of a counterion condensed per original polyion charge $\left(\psi_{c}=\right.$ 0.43 for single-stranded DNA). In the presence of both monovalent $\left(\mathrm{Na}^{+}\right)$and polyvalent cations (e.g. $\left.\mathrm{Mg}^{2+}\right), \log \mathrm{k}_{\text {off }}$ is no longer a linear function of the $\log$ of monovalent salt concentration. Moreover, $K_{o b s}^{M g}$ depends on the salt concentration as described by Record et al. [59] and is given by:

$\log K_{o b s}^{M g}=-2 \psi \log \left[M^{+}\right]+\log K_{T}^{M g}$

where $\log K_{T}^{M g}$ is the thermodynamic equilibrium constant for $\mathrm{Mg}^{2+}$ ion binding to the nucleic acid and $\psi$ is the thermodynamic binding parameter, which includes both the extent of condensation $\left(\psi_{\mathrm{c}}\right)$ and the contribution due to screening effects $\left(\psi_{\mathrm{s}}\right) \quad(\psi=0.71$ for single-stranded DNA). The value of $\log K_{T}^{M g}$ is reported to vary between 0 and 1 depending on type of nucleic acid and buffer composition [59]. The $\log \mathrm{k}_{\text {off }}$ vs $\log [\mathrm{NaCl}]$ plot was fitted with Equation 11 using the Solver tool in Microsoft Office Excel. To find the best fit, $\mathrm{Z}$ and $\log K_{T}^{M g}$ were varied to minimize the sum of the squared residuals (experimental $k_{\text {off }}$ - predicted $k_{\text {off }}$ ) for all four salt concentrations at each temperature.

\subsection{Effect of $\mathrm{MgCl}_{2}$ on D17.4/IgE complex dissociation kinetics}

The effect of $\left[\mathrm{Mg}^{+2}\right]$ on the dissociation kinetics of the $\mathrm{D} 17.4 / \mathrm{IgE}$ complex was investigated at $1 \mathrm{mM}$ and $20 \mathrm{mM} \mathrm{MgCl}$, in the buffer containing $8.1 \mathrm{mM} \mathrm{Na} 2 \mathrm{HPO}_{4}, 1.1 \mathrm{mM}$ 
$\mathrm{KH}_{2} \mathrm{PO}_{4}, 2.7 \mathrm{mM} \mathrm{KCl}$, and $138 \mathrm{mM} \mathrm{NaCl}, \mathrm{pH} 7.4$ at $25{ }^{\circ} \mathrm{C}$ (Fig. 4). This 20 -fold increase in $\mathrm{MgCl}_{2}$ concentration at $138 \mathrm{mM} \mathrm{NaCl}, \mathrm{pH} 7.4$ and $25{ }^{\circ} \mathrm{C}$ resulted in a $\sim 4.5$-fold increase in ensemble $\mathrm{k}_{\text {off }}$ from $(5.51 \pm 0.22) \times 10^{-3} \mathrm{~s}^{-1}$ to $(2.41 \pm 0.13) \times 10^{-2} \mathrm{~s}^{-1}$.

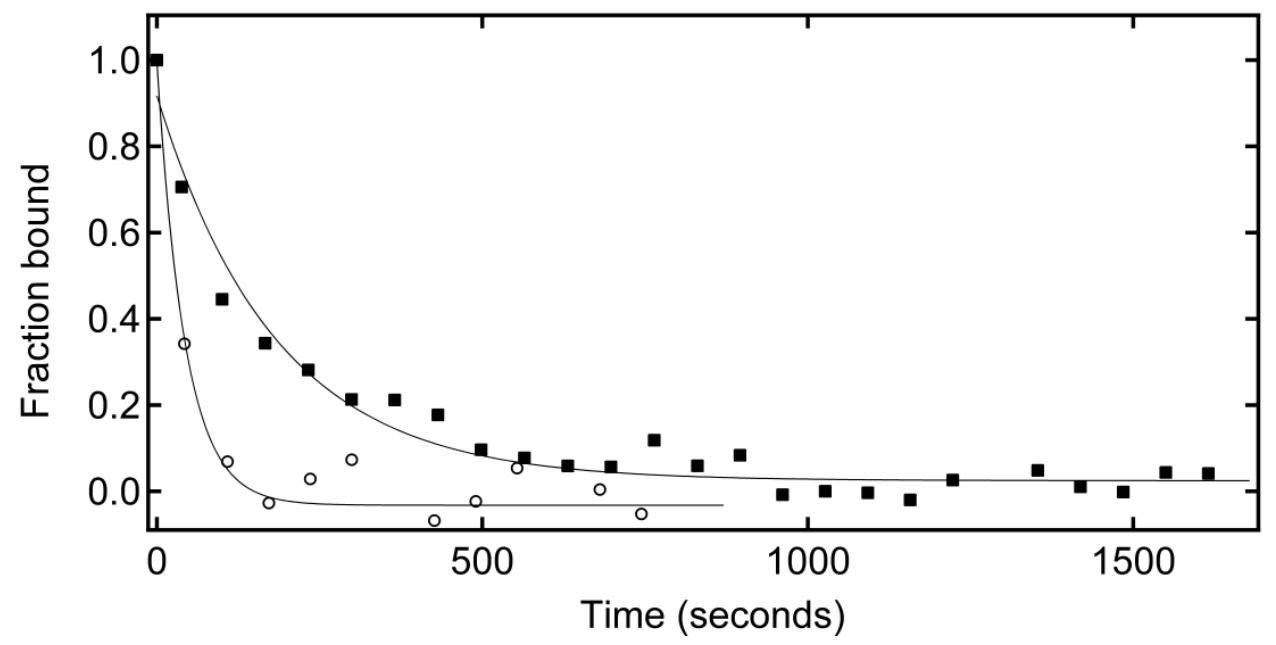

Fig. 4. Representative D17.4/IgE dissociation kinetics at $1 \mathrm{mM}$ and $20 \mathrm{mM} \mathrm{Mg}{ }^{2+}$. Dissociation profiles of Texas Red-labeled D17.4 aptamer pre-complexed with IgE in $8.1 \mathrm{mM} \mathrm{Na}_{2} \mathrm{HPO}_{4}, 1.1$ $\mathrm{mM} \mathrm{KH}_{2} \mathrm{PO}_{4}, 2.7 \mathrm{mM} \mathrm{KCl}$, and $138 \mathrm{mM} \mathrm{NaCl}, \mathrm{pH} 7.4$ at $25^{\circ} \mathrm{C}$, with either $1 \mathrm{mM}(\mathbf{m})$ or $20 \mathrm{mM}$ $\mathrm{MgCl}_{2}$ (०); A first-order, single-exponential model was used to describe the dissociation data (solid lines). The $\mathrm{k}_{\text {off }}$ at $1 \mathrm{mM}$ and $20 \mathrm{mM} \mathrm{MgCl} 2$ are $(5.51 \pm 0.22) \times 10^{-3} \mathrm{~s}^{-1}$ and $(2.41 \pm 0.13) \times 10^{-2} \mathrm{~s}^{-}$ 1 .

We previously observed reduced aptamer affinity with increasing $\mathrm{MgCl}_{2}$ concentration for both an anti-lysozyme aptamer/lysozyme and the aV aptamer/VEGF interaction [29, 30]. The effect of increasing $\mathrm{MgCl}_{2}$ concentration on dissociation rate can be partly attributed to the increase in the ionic strength, but the major contribution arises from the effect of $\mathrm{Mg}^{2+}$ ions on the conformation of the aptamer. Divalent cations such as $\mathrm{Mg}^{2+}$ ions promote folding and structuring of nucleic acids $[29,30]$ and may decrease the conformational flexibility of the aptamer and/or result in a conformation less capable of recognizing the target. Mfold structure prediction suggested the presence of two possible aptamer structures at $20 \mathrm{mM} \mathrm{MgCl}_{2}$, compared to a single stem-loop structure at $1 \mathrm{mM} \mathrm{MgCl} 2$ (both at $138 \mathrm{mM} \mathrm{NaCl}$ and $25{ }^{\circ} \mathrm{C}$ ). The two 
structures at $20 \mathrm{mM} \mathrm{MgCl} 2$ are shown in Fig. 5, with one of the structures adopting a two-stemloop conformation (Fig. 5B) and the second displaying a single stem-loop (Fig. 5C; which is the same structure as at $1 \mathrm{mM} \mathrm{MgCl}$, Fig. 5A); no significant difference was observed in the anisotropy of free aptamer at the two different $\mathrm{Mg}$ concentrations. A decrease in affinity of the D17.4 aptamer for IgE in the presence of $20 \mathrm{mM} \mathrm{MgCl}_{2}$ (plus $138 \mathrm{mM} \mathrm{NaCl}$ at $25^{\circ} \mathrm{C}$ ) compared to $1 \mathrm{mM} \mathrm{MgCl}_{2}$ was proposed based on the difference in the observed anisotropy just before inducing dissociation $\left(\mathrm{A}_{\mathrm{b}}\right)$. At $25{ }^{\circ} \mathrm{C}$ and $138 \mathrm{mM} \mathrm{NaCl}, \mathrm{A}_{\mathrm{b}}$ decreased by $\sim 7 \%$ in a buffer containing $20 \mathrm{mM} \mathrm{MgCl}_{2}\left(\mathrm{~A}_{\mathrm{b}}=0.087\right)$ compared to $1 \mathrm{mM} \mathrm{MgCl} 2\left(\mathrm{~A}_{\mathrm{b}}=0.094\right)$.
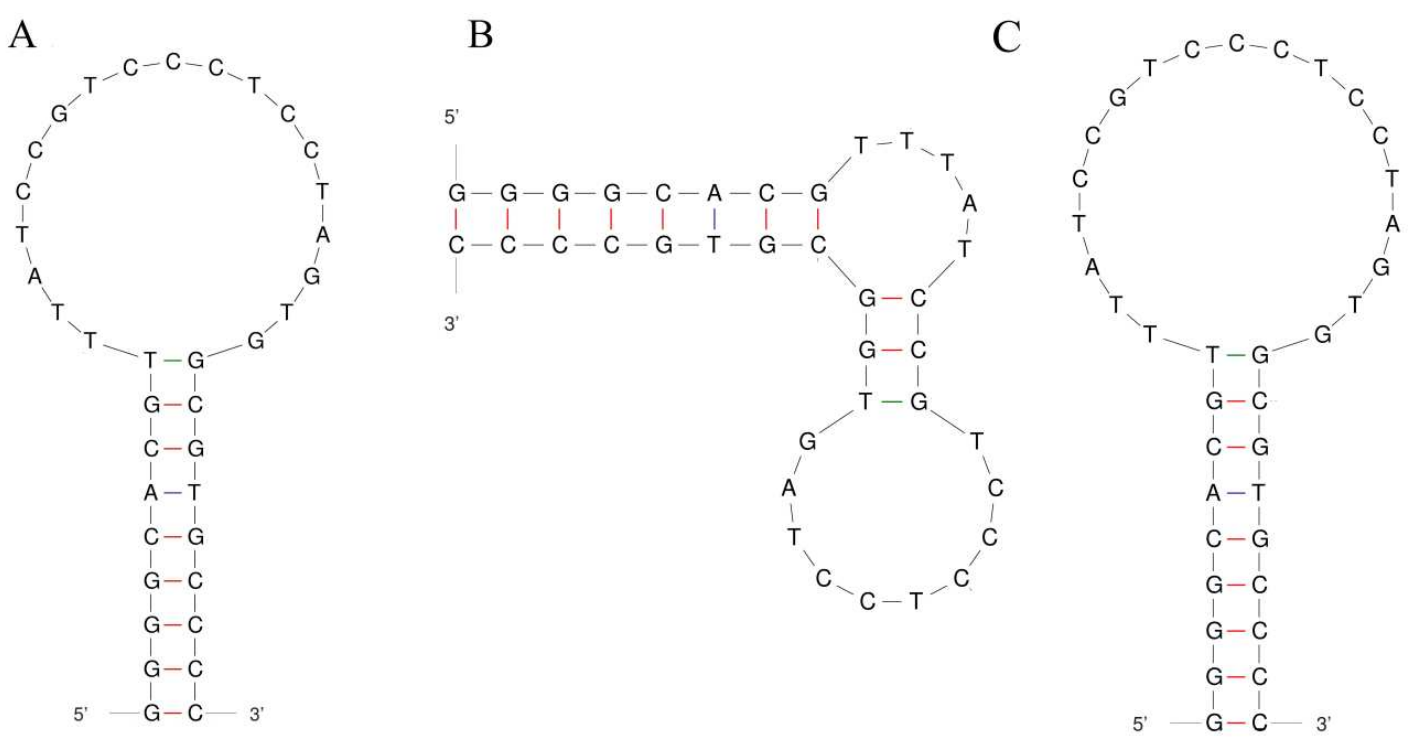

Fig. 5. Effect of $\mathrm{MgCl}_{2}$ on mfold-predicted secondary structure of D17.4 DNA aptamer. $\left[\mathrm{Na}^{+}\right]=138 \mathrm{mM}$ at $25^{\circ} \mathrm{C}$. (A) $\left[\mathrm{Mg}^{2+}\right]=1 \mathrm{mM} ; \Delta \mathrm{G}=-9.93 \mathrm{kcal} / \mathrm{mol}(\mathrm{B})\left[\mathrm{Mg}^{2+}\right]=20 \mathrm{mM} ; \Delta \mathrm{G}=-$ $9.94 \mathrm{kcal} / \mathrm{mol}$ and $(\mathrm{C})$ Alternative structure for $\left[\mathrm{Mg}^{2+}\right]=20 \mathrm{mM} ; \Delta \mathrm{G}=-10.73 \mathrm{kcal} / \mathrm{mol}$.

Our results are in agreement with a previous atomic force microscopy (AFM) study of D17.4 aptamer/IgE interaction by Jiang et al. [60] which showed a decrease in both the rupture force and the average number of bonds formed between the $\operatorname{IgE}$ and D17.4 aptamer with increasing $\mathrm{MgCl}_{2}$ concentration (from 1 to $10 \mathrm{mM} \mathrm{MgCl}_{2}$ in PBS buffer). Taken together, we 
attribute the strong increase in $\mathrm{k}_{\text {off }}$ at high $\mathrm{MgCl}_{2}$ concentration to the lowered affinity of D17.4 aptamer for $\mathrm{IgE}$, most likely due to structural changes in the D17.4 aptamer at high $\mathrm{MgCl}_{2}$ concentration.

\subsection{Dissociation kinetics of mutant anti-IgE aptamers}

Investigation of the relationships between the aptamer sequence, structure and binding affinity is important for a complete understanding of the molecular mechanisms of aptamerprotein interactions [61-63]. The 37-nucleotide D17.4 aptamer folds into a stem-loop structure, and previous studies have shown that the stem region provides stability to the aptamer, whereas the majority of nucleotides in the loop region (nucleotides 9-29) appears to be involved in interactions with $\operatorname{IgE}[12,52]$.

The mutant aptamers D17.4-C19A (Fig. 6A; C at position 19 in the loop region replaced by A), D17.4-G1T (Fig. 6B; G at position 1 in the stem replaced by T), and D17.4-C19G (Fig. 6C; $\mathrm{C}$ at position 19 in the loop replaced by $\mathrm{G}$ ), were chosen based on the location of the nucleotide in the predicted structure, and previous microarray binding experiments which provided indications of their relative binding affinities [12, 52]. All mutant dissociation experiments were performed in $8.1 \mathrm{mM} \mathrm{Na}_{2} \mathrm{HPO}_{4}, 1.1 \mathrm{mM} \mathrm{KH} \mathrm{PO}_{4}, 2.7 \mathrm{mM} \mathrm{KCl}, 1 \mathrm{mM} \mathrm{MgCl} 2$ and $138 \mathrm{mM} \mathrm{NaCl}, \mathrm{pH} \mathrm{7.4}$, at $25{ }^{\circ} \mathrm{C}$ unless specified otherwise. In cross-competition experiments, where the D17.4-G1T/IgE complex and D17.4-C19G/IgE complex were dissociated with excess (50-fold) unlabeled D17.4 as the competitor, the dissociation rate $\left(\mathrm{k}_{\text {off }}\right)$ was calculated to be $(5.72 \pm 0.05) \times 10^{-3} \mathrm{~s}^{-1}$ for D17.4-G1T/IgE complex and $(5.64 \pm 0.35) \times 10^{-3} \mathrm{~s}^{-1}$ for D17.4-C19G/IgE complex (data not shown). The measured $\mathrm{k}_{\text {off }}$ values for the two mutants were similar to the D17.4/IgE complex, $\mathrm{k}_{\text {off }}=(5.51 \pm 0.22) \times 10^{-3} \mathrm{~s}^{-1}$ when dissociated with excess (50-fold) unlabeled D17.4 as the competitor. The aptamers D17.4-G1T, D17.4- C19G and D17.4 
all show the same (stem-loop) mfold-predicted structures with similar $\Delta \mathrm{G}$ values suggesting a similarity in aptamer structures might be an important reason for the observed similar $\mathrm{k}_{\text {off }}$ values.

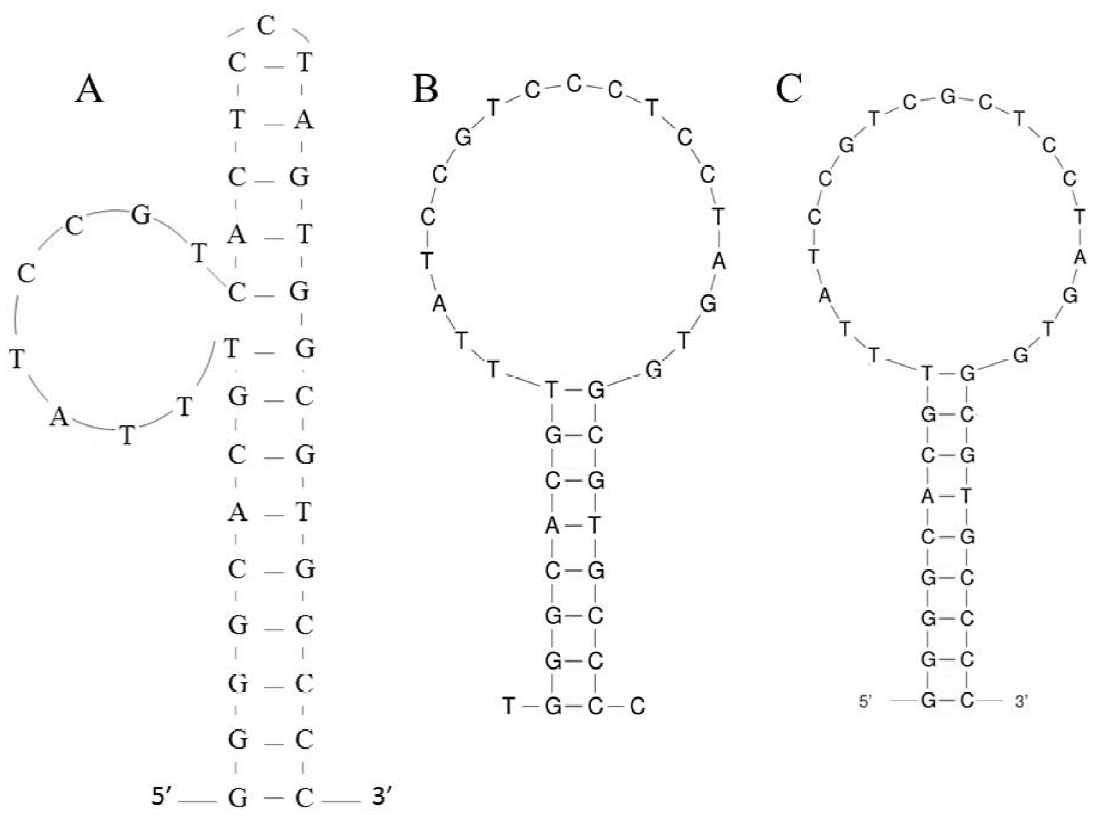

Fig. 6. Mfold-predicted secondary structures of the mutant aptamers in $\left[\mathrm{Na}^{+}\right]=138 \mathrm{mM}$, $\left[\mathrm{Mg}^{2+}\right]=1 \mathrm{mM}$ at $25^{\circ} \mathrm{C}$. (A) D17.4-C19A, (B) D17.4-GIT, $\Delta \mathrm{G}=-9.03 \mathrm{kcal} / \mathrm{mol}$ and (C) D17.4$\mathrm{C} 19 \mathrm{G}, \Delta \mathrm{G}=-9.93 \mathrm{kcal} / \mathrm{mol}$. For comparison, recall that for the original 17.4 sequence $\Delta \mathrm{G}=-$ $9.93 \mathrm{kcal} / \mathrm{mol}$.

Our results showing similar $\mathrm{k}_{\text {off }}$ for the D17.4-G1T and D17.4 aptamers are in agreement with the previously published SPR results [52] which reported similar $\mathrm{k}_{\text {off }}$ values for D17.4-G1T $\left(\mathrm{k}_{\mathrm{off}}=\right.$ $\left.2.3 \times 10^{-3} \mathrm{~s}^{-1}\right)$ and D17.4 aptamer $\left(\mathrm{k}_{\text {off }}=2.0 \times 10^{-3} \mathrm{~s}^{-1}\right)$ in a buffer containing $138 \mathrm{mM} \mathrm{NaCl}, 1 \mathrm{mM}$ $\mathrm{MgCl}_{2}$, at room temperature. Based on the previous [52] reported $\mathrm{k}_{\mathrm{d}}$ value from anisotropy experiments $\left(\mathrm{k}_{\mathrm{d}}\right.$ for D17.4-G1T aptamer $=7 \pm 2 \mathrm{nM}$ compared to $\mathrm{k}_{\mathrm{d}}=15 \pm 4 \mathrm{nM}$ for D17.4 aptamer in $138 \mathrm{mM} \mathrm{NaCl}, 1 \mathrm{mM} \mathrm{MgCl}_{2}$, at room temperature), a different $\mathrm{k}_{\text {off }}$ compared to D17.4 was expected. Our previous SPR studies on aV aptamer/VEGF interaction [29] showed that the 0C mutation (a 5' single-nucleotide extension) resulted in a considerable enhancement in affinity, 
with an 11-fold higher association rate and a dissociation rate comparable to aV. Hence, it is possible that an increase in affinity might involve an increase in the $\mathrm{k}_{\text {on }}$ value without altering the $\mathrm{k}_{\text {off }}$ value for D17.4-G1T/IgE. Results from previous microarray binding studies [52] showed that the D17.4-C19G aptamer gave a 4-fold lower intensity of binding compared to the original D17.4 sequence, suggesting that $\mathrm{C} 19 \mathrm{G}$ might show more rapid dissociation than the parent. In contrast, our ensemble dissociation results showed similar $\mathrm{k}_{\text {off }}$ values for the parent D17.4 and mutant D17.4-C19G aptamers. Though there are no prior studies on D17.4-C19G aptamer, D17.4-C19T (with a mutation in the same position to $\mathrm{T}$ instead of $\mathrm{G}$ ) also showed ensemble $\mathrm{k}_{\text {off }}$ similar to D17.4 by SPR [52]; $\mathrm{k}_{\text {off }}=2.1 \times 10^{-3} \mathrm{~s}^{-1}$ for D17.4- C19T and $\mathrm{k}_{\text {off }}=2.0 \times 10^{-3} \mathrm{~s}^{-1}$ for D17.4 aptamer at $138 \mathrm{mM} \mathrm{NaCl}, 1 \mathrm{mM} \mathrm{MgCl}_{2}$, at room temperature. The C19A replacement leads to a different mfold-predicted structure with a longer predicted stem. As shown in Fig. 7, the dissociation of the $\mathrm{C} 19 \mathrm{~A} / \mathrm{IgE}$ complex is $20 \%$ slower than that of the parent $\left(\mathrm{k}_{\mathrm{off}}=\right.$ $(4.51 \pm 0.02) \times 10^{-3} \mathrm{~s}^{-1}$ vs. $\left.(5.51 \pm 0.22) \times 10^{-3} \mathrm{~s}^{-1}\right)$ at $25^{\circ} \mathrm{C}, 1 \mathrm{mM} \mathrm{MgCl}_{2}$ and $138 \mathrm{mM} \mathrm{NaCl}$, possibly due to enhanced stability of the aptamer.

Cross-competition experiments, in which 20-fold excess unlabeled D17.4-C19A mutant was used as the competitor for the dissociation of D17.4/IgE complex, resulted in only partial dissociation (40-50\% dissociation at 3000 s). Increasing the concentration of the unlabeled D17.4-C19A competitor (from 50- to 80- fold excess) did not increase the extent of dissociation significantly. Wiegand et al. [12] reported an IgE-binding RNA aptamer, IGEL 2.2 (IGEL 2.2 sequence: 5'-GGGAGGACGAUGCGGGUGUGGGGCG-3') that induced only partial dissociation of the D17.4/IgE complex. Wiegand et al. [12] speculated that there exists a second aptamer binding site in IgE that acts as binding site for IGEL2.2, likely in the same vicinity and possibly overlapping with the binding site of the D17.4 aptamer. This notion was supported by 
experimental results that showed IGEL2.2 does not block the IgE/FceRI interaction, unlike D17.4. Though there is no sequence (or structure) similarity between IGEL2.2 and D17.4-C19A, we speculate that the D17.4-C19A mutant aptamer may bind to or overlap this second site.

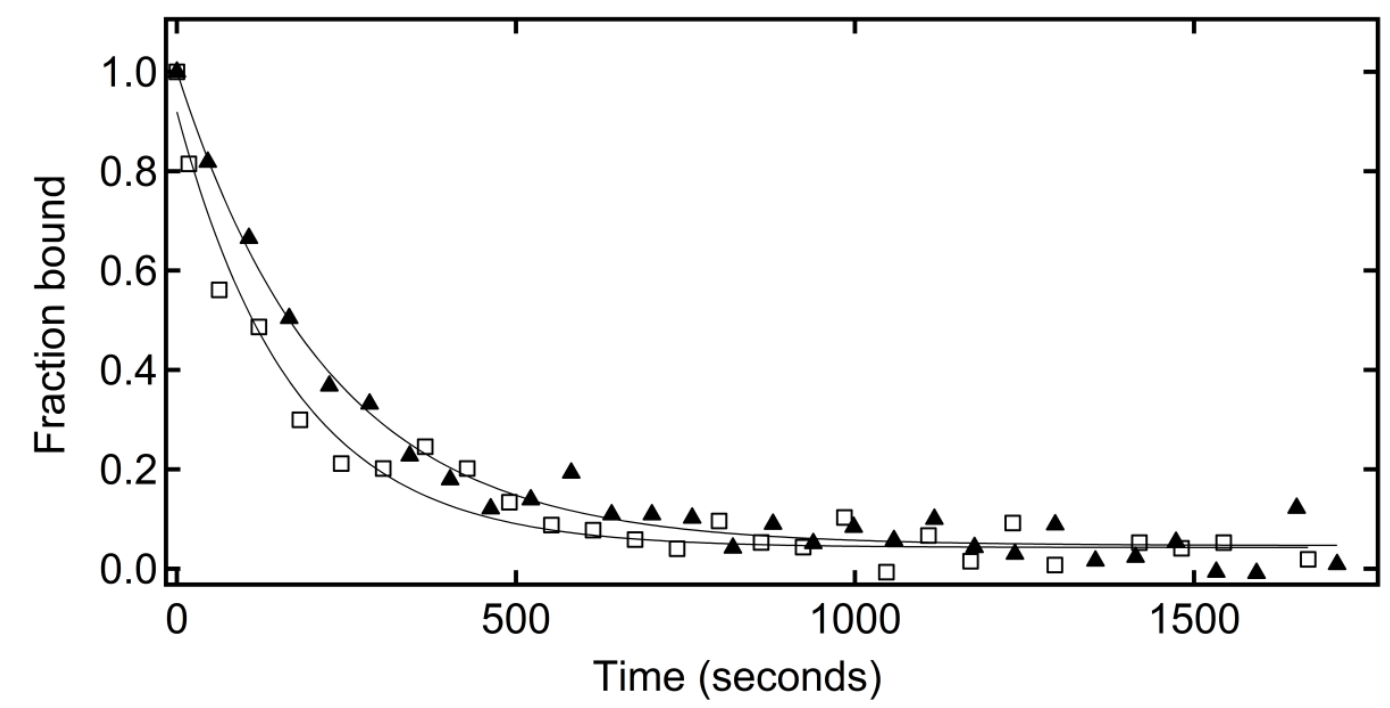

Fig. 7. Effect of aptamer mutation on dissociation kinetics. Typical dissociation profiles of 40 $\mathrm{nM}$ Texas-Red labeled D17.4 () and D17.4-C19A ( $\mathbf{\Delta})$ aptamer complexed with $320 \mathrm{nM} \mathrm{IgE}$ in $138 \mathrm{mM} \mathrm{NaCl}, 1 \mathrm{mM} \mathrm{MgCl} 2$ and $25^{\circ} \mathrm{C}$, and dissociated with $2000 \mathrm{nM}$ unlabeled D17.4 aptamer. A first-order, single-exponential model was used to describe the dissociation data (solid lines).

The cross and self-competition experiments in which D17.4-C19A/IgE complex was dissociated with excess unlabeled D17.4 or C19A aptamer, at $138 \mathrm{mM} \mathrm{NaCl}, 1 \mathrm{mM} \mathrm{MgCl} \mathrm{Mn}_{2}$ and $25{ }^{\circ} \mathrm{C}$ gave similar $\mathrm{k}_{\text {off }}$ values and near complete dissociation (as discussed in methods) suggesting the dissociation of D17.4-C19A/IgE complex is unaffected by the competitor used.

3.4 Single-molecule investigation of short-time aptamer/IgE interactions at $25^{\circ} \mathrm{C}$

Wide-field TIRF microscopy was used to investigate aptamer/IgE interactions (Fig. 8) on shorter time scales and free of ensemble averaging, as we have previously applied to aptamer and protein adsorption processes $[33,64,65]$. Fig. 8 A shows a schematic of the surface chemistry on 
the glass cover slips used to immobilize the aptamers, and Fig. 8B shows the home-built TIRF microscope. As a control to confirm that the sample preparation methods used produced immobilized aptamer densities at which single aptamers were individually resolvable, we immobilized Cy5-labeled aptamer (250 pM) using the same immobilization procedure as for the unlabeled biotinylated aptamer. As shown in Fig. 8C, aptamer binding sites are resolvable and well-separated, at an approximate density of $1.0 \pm 0.3 \mathrm{aptamer} / \mu \mathrm{m}^{2}$.

The interactions between the labeled $\operatorname{IgE}$ and the stationary aptamer phase were tuned to be infrequent and reversible via low aptamer loading on the glass coverslip (Fig. 8C), low labeled protein concentration $(500 \mathrm{pM})$, and use of a salt concentration chosen to make the average duration of adsorption events suitable for effective observation. The diffusion constant (D $\sim 4 \mu \mathrm{m}^{2} / \mathrm{s}$ ) of $\mathrm{IgE}$ in bulk solution compared to the detector integration time (30 ms) allowed for the free antibody to be unobservable due to motion blur at flow rates of $5 \mu \mathrm{L} / \mathrm{min}$ (Fig. 8A). Thus, stochastic on/off behavior of the fluorescently labeled IgE to the immobilized aptamer at the interface allows for detection of individual adsorption/desorption events [34, 50]. We observed 4000 single molecule on/off events to obtain the reported statistics, a typical number for single- molecule experiments [66]. A series of five 1000-frame series (or five 62-s trials) was collected. 


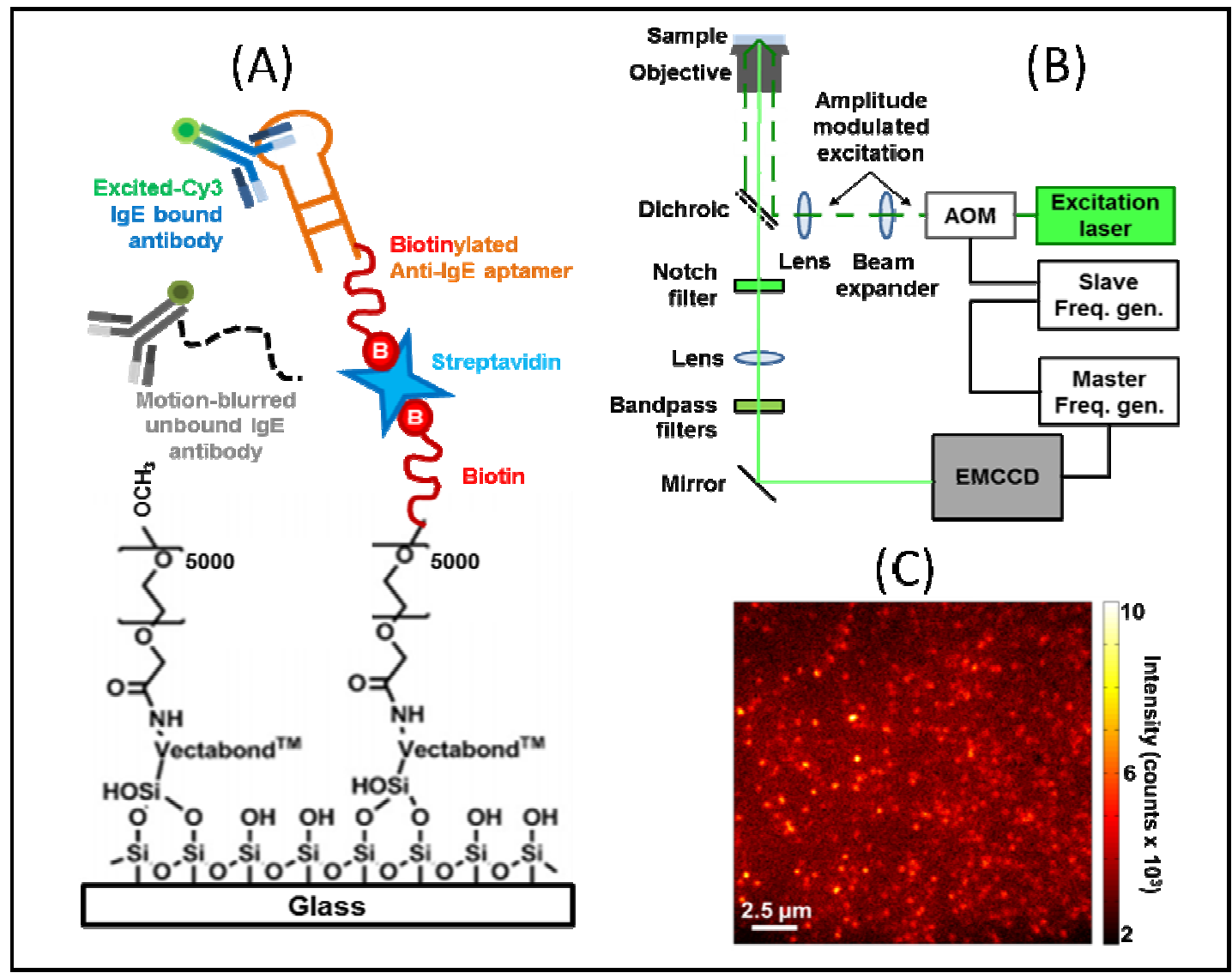

Fig. 8. (A) Surface chemistry schematic showing aptamer immobilization on functionalized glass coverslips. (B) TIRF instrument schematic, highlighting AOMs/frequency generators. (C) Single molecule image of $250 \mathrm{pM}$ (offered) Cy5-labeled anti-IgE aptamer showing individuallyresolvable aptamers; binned 10 frames (300 ms total).

To control for possible effects of fluorophore photophysics (which, e.g., could make slow kinetics unobservable because of photobleaching) we observed the samples at varying collection frequencies and at varied salt concentrations. Based on our understanding that salt concentration decreases the timescale of the aptamer/IgE interaction as shown in Fig. 3 (ensemble), we varied salt from $200-400 \mathrm{mM} \mathrm{NaCl}$ for the single molecule results shown in Fig. 9 (note the difference in the observed event time scales in Figs. 3 and 9). However, at low salt concentrations data collection was limited by photophysics; at 200 (data not shown) and 300 (Fig. 9A) mM NaCl the long time-scale kinetics do not converge. That is, collection of data at intervals of $1 / 16 \mathrm{~s}$ to $1 \mathrm{~s}$ 
could affect the ability to observe events at the shorter end of the range, but at longer periods of 5-20 s, to be reliable the results should be independent of collection frequency, this is observed only at $400 \mathrm{mM}$ (Fig. 9B), where the observed kinetics are faster. These data converge at $1-2 \mathrm{~Hz}$ (similar frequencies of events of length 4000-7000 ms), implying that photobleaching does not contribute significantly to the results at these conditions. Therefore, quantitative analysis was achieved by fitting the cumulative distribution for $400 \mathrm{mM} \mathrm{NaCl}$ at $2 \mathrm{~Hz}$ frame collection frequency to a three-component exponential decay using standard curve-fitting considerations [67] (Fig. 9B, solid line) to account for the heterogeneity present among binding events [68].
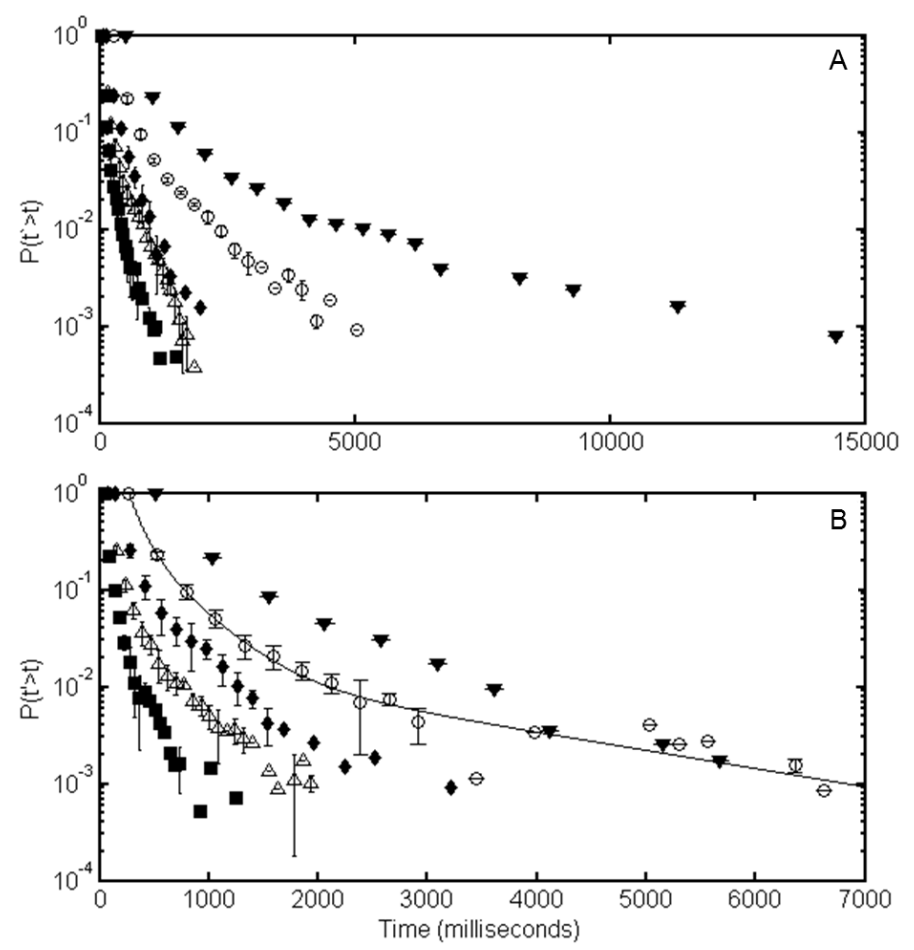

Fig. 9. (A) Desorption kinetics at $25^{\circ} \mathrm{C}$ and $300 \mathrm{mM} \mathrm{NaCl}$ fail to converge compared to (B) convergence at $25^{\circ} \mathrm{C}$ and $400 \mathrm{mM} \mathrm{NaCl}$ for data collected at variable frequency collection rates. Semi-log plots of cumulative distributions of desorption times at variable frequencies; $16 \mathrm{~Hz}(\mathbf{\square})$, $8 \mathrm{~Hz}(\Delta), 4 \mathrm{~Hz}(\bullet), 2 \mathrm{~Hz}$ ( $\circ$; solid line is a three-component exponential decay fit), and $1 \mathrm{~Hz}(\boldsymbol{\nabla})$. In (A) $2 \mathrm{~Hz}$ and $1 \mathrm{~Hz}$ do not converge (desorption times beyond $5000 \mathrm{~ms}$ ) due to photobleaching at $2 \mathrm{~Hz}$. Measurement at rates below $1 \mathrm{~Hz}$ is not stable due to sample drift, therefore it cannot be determined whether there are kinetics beyond the observation time scale. Comparatively, in (B) 1 and $2 \mathrm{~Hz}$ have similar decays and converge $\sim 4000 \mathrm{~ms}$. 
The single-molecule observations of immobilized aptamer/IgE complexes at conditions not affected by photophysics show heterogeneous dissociation rates (in agreement with a multicomponent fit) at a range much faster than those observed in the ensemble experiments in solution. The resulting $\mathrm{k}_{\text {off }}$ values are $9.3 \pm 0.9,2.6 \pm 0.3$, and $0.43 \pm 0.15 \mathrm{~s}^{-1}$ with amplitude contributions of $66 \pm 6,32 \pm 6$, and $1.7 \pm 0.8 \%$, respectively. This difference may arise from steric hindrance or electrostatic interactions with the surface, or from the surface-entropic penalty of binding the large antibody.

\subsection{Temperature effects and energetics of aptamer-protein dissociation kinetics}

The temperature dependence of the D17.4/IgE complex dissociation was studied in the temperature range $10-30{ }^{\circ} \mathrm{C}$ (Fig. 10). The dissociation rate showed a strong temperature dependence ( 9-fold increase), increasing from $(1.17 \pm 0.09) \times 10^{-3} \mathrm{~s}^{-1}$ in $138 \mathrm{mM} \mathrm{NaCl}, 1 \mathrm{mM}$ $\mathrm{MgCl}_{2}$ at $10{ }^{\circ} \mathrm{C}$ to $(1.05 \pm 0.06) \times 10^{-2} \mathrm{~s}^{-1}$ in $138 \mathrm{mM} \mathrm{NaCl}, 1 \mathrm{mM} \mathrm{MgCl}_{2}$, at $30{ }^{\circ} \mathrm{C}$. At $37{ }^{\circ} \mathrm{C}$ the dissociation rate further increased to $(2.03 \pm 0.13) \times 10^{-2} \mathrm{~s}^{-1}$. Similarly, the temperature dependence of D17.4-C19A/IgE dissociation was shown by an approximate 8-fold increase in dissociation rate from $(9.20 \pm 0.9) \times 10^{-4} \mathrm{~s}^{-1}$ at $10{ }^{\circ} \mathrm{C}$ to $(7.24 \pm 0.28) \times 10^{-3} \mathrm{~s}^{-1}$ at $30{ }^{\circ} \mathrm{C}$ in binding buffer containing $138 \mathrm{mM} \mathrm{NaCl}$ and $1 \mathrm{mM} \mathrm{MgCl}_{2}$. Potty et al. [30] previously studied the association of antilysozyme aptamer/lysozyme at different temperatures and attributed the observed decrease in affinity with increasing temperature to the progressive destabilization of the anti-lysozyme aptamer structure. 


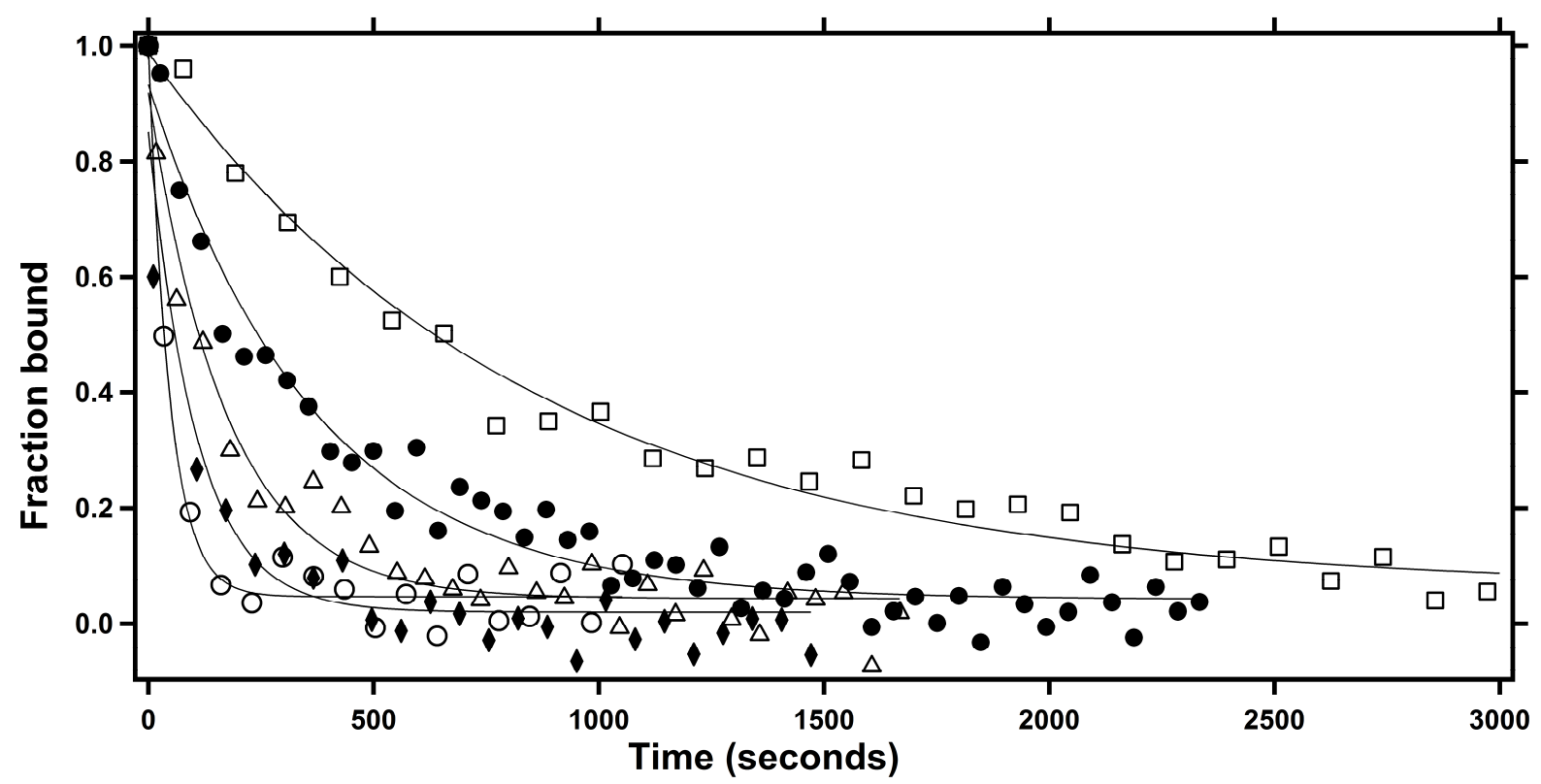

Fig. 10. Effect of temperature on aptamer-protein dissociation kinetics. Representative dissociation profiles of Texas-Red labeled D17.4 aptamer pre-complexed with IgE at various temperatures $10^{\circ} \mathrm{C}(\square), 20^{\circ} \mathrm{C}(\bullet), 25^{\circ} \mathrm{C}(\Delta), 30^{\circ} \mathrm{C}(\bullet)$ and $37^{\circ} \mathrm{C}(\mathrm{o})$ in binding buffer containing $138 \mathrm{mM} \mathrm{NaCl}$ and $1 \mathrm{mM} \mathrm{MgCl} 2$. A first-order, single-exponential model was used to describe the dissociation data (solid lines).

The effect of temperature on the conformational flexibility of the D17.4 aptamer was validated by our anisotropy data $(\sim 1.45$-fold decrease in the anisotropy of free aptamer as temperature is increased from $10{ }^{\circ} \mathrm{C}$ to at $30{ }^{\circ} \mathrm{C}$ in $1 \mathrm{mM} \mathrm{MgCl}_{2}$ ). The dissociation kinetics of the D17.4/IgE complex was studied at varying temperatures $\left(10{ }^{\circ} \mathrm{C}, 20{ }^{\circ} \mathrm{C}, 25{ }^{\circ} \mathrm{C}\right.$, and $\left.30{ }^{\circ} \mathrm{C}\right)$ at each $\mathrm{NaCl}$ concentration $(50,138,200$, and $300 \mathrm{mM}$ ). From the Arrhenius plots (Fig. 11), the activation parameters for $\mathrm{D} 17.4 / \mathrm{IgE}$ dissociation were found to be $\Delta H^{\#}=17.9 \pm 1.6 \mathrm{kcal} \mathrm{mol}^{-1}$ and $\Delta S^{\#}=-8.7 \pm 5.6 \mathrm{cal} \mathrm{mol}^{-1} \mathrm{~K}^{-1}$ at $138 \mathrm{mM} \mathrm{NaCl}$ and $1 \mathrm{mM} \mathrm{MgCl}_{2}$. Thus at $298 \mathrm{~K}$ there is an activation free energy barrier of $\Delta G^{\#}=20.5 \pm 2.3 \mathrm{kcal} \mathrm{mol}^{-1}$ for the dissociation reaction. The enthalpy change of activation $\left(\Delta H^{\#}\right)$ is the main component of the free energy change of activation $\left(\Delta G^{\#}\right)$. Dissociation also was studied at $37{ }^{\circ} \mathrm{C}$, though at only one ionic strength (138 
$\mathrm{mM} \mathrm{NaCl}$ ) as the kinetic data was less good at higher dissociation rates. However results at that salt condition further confirm the linearity of the Arrhenius plot over the temperature range from 10 to $37^{\circ} \mathrm{C}$.

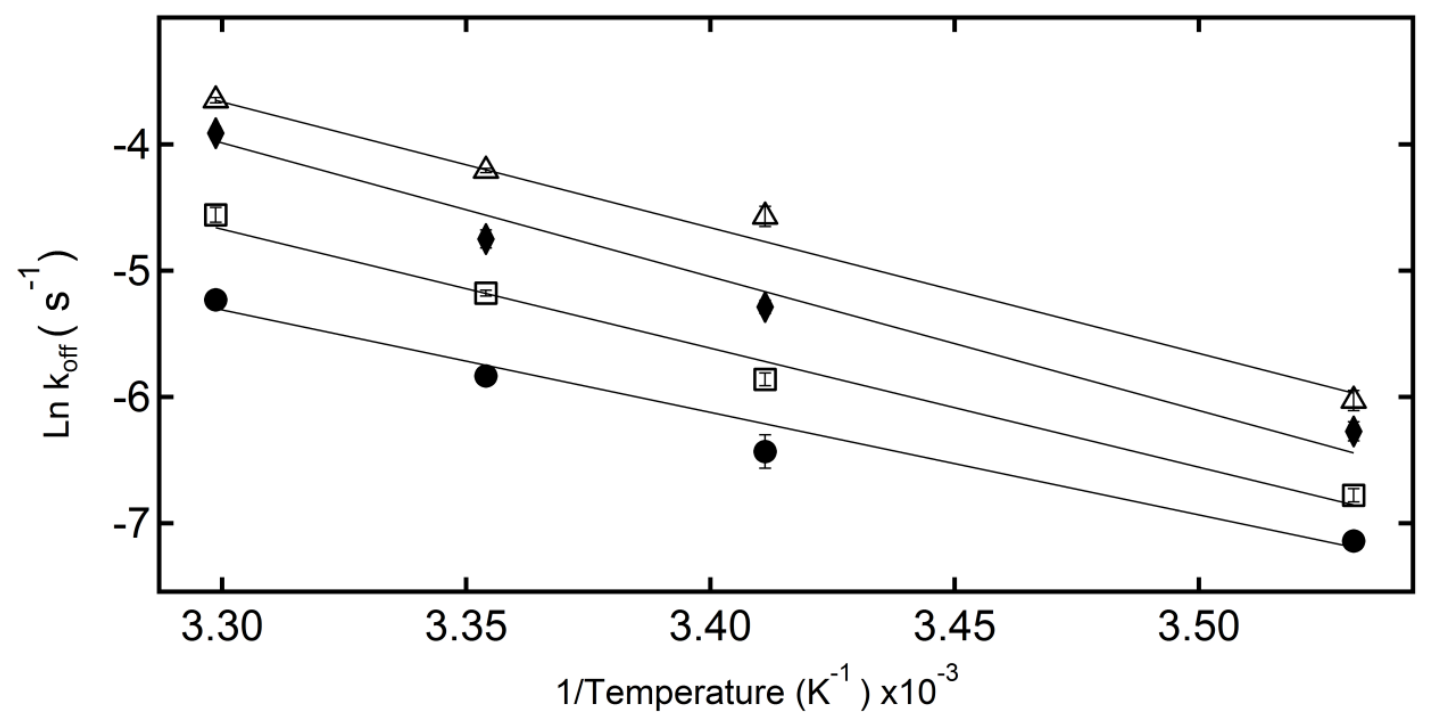

Fig. 11. Arrhenius plots for dissociation of D17.4/IgE complex as a function of temperature at different salt concentrations; $50 \mathrm{mM}(\bullet), 138 \mathrm{mM}(\square), 200 \mathrm{mM}(\diamond)$ and $300 \mathrm{mM} \mathrm{NaCl}(\Delta)$. A linear regression fit to the data gave a slope which was used to determine the activation energy $\left(\mathrm{E}_{\mathrm{a}}\right)$ as given in Equations 5 and 6 . The values of activation parameters obtained from fit are summarized in Table 1. Points are average $+/-\operatorname{Std}$ Dev, $n=3$.

Table 1. Activation parameters for the dissociation of D17.4/IgE complex at various salt concentrations.

\begin{tabular}{|c|c|c|c|c|}
\hline \multirow{2}{*}{$\begin{array}{c}\text { Activation } \\
\text { parameter }\end{array}$} & \multicolumn{4}{|c|}{ NaCl (mM) } \\
\cline { 2 - 5 } & $\mathbf{5 0}$ & $\mathbf{1 3 8}$ & $\mathbf{2 0 0}$ & $\mathbf{3 0 0}$ \\
\hline $\begin{array}{c}\mathrm{E}_{\mathrm{a}} \\
(\mathrm{kcal} / \mathrm{mol})\end{array}$ & $16.0 \pm 1.9$ & $18.5 \pm 1.6$ & $19.3 \pm 2.0$ & $20.1 \pm 1.5$ \\
\hline $\begin{array}{c}\Delta H^{\#} \\
(\mathrm{kcal} / \mathrm{mol})\end{array}$ & $15.4 \pm 1.9$ & $17.9 \pm 1.6$ & $18.7 \pm 2.0$ & $19.5 \pm 1.5$ \\
\hline $\begin{array}{c}\Delta S^{\#} \\
(\mathrm{cal} / \mathrm{mol} / \mathrm{K})\end{array}$ & $-18.5 \pm 6.7$ & $-8.7 \pm 5.6$ & $-5.1 \pm 6.8$ & $-1.5 \pm 5.2$ \\
\hline $\begin{array}{c}\mathrm{T} \Delta S^{\#} \\
(\mathrm{kcal} / \mathrm{mol})\end{array}$ & $-5.5 \pm 1.9$ & $-2.5 \pm 1.6$ & $-1.51 \pm 2.0$ & $-0.44 \pm 1.6$ \\
\hline
\end{tabular}




\begin{tabular}{|c|c|c|c|c|}
\hline $\begin{array}{c}\Delta G^{\#} \\
(\mathrm{kcal} / \mathrm{mol})\end{array}$ & $20.8 \pm 2.8$ & $20.5 \pm 2.3$ & $20.2 \pm 2.8$ & $19.9 \pm 2.2$ \\
\hline
\end{tabular}

The dissociation of the D17.4- $\operatorname{IgE}$ complex is unfavorable in terms of both entropy and enthalpy of activation. Our previous studies on the dissociation kinetics of HyHEL-5 antibodybobwhite quail lysozyme (BWQL) complex, showed that the dissociation involves an unfavorable enthalpy change [69]. The large unfavorable activation enthalpy $\left(\Delta H^{\#}\right)$ for the dissociation of the complexes indicates that the major barrier for the dissociation involves breaking of noncovalent bonds between the binding partners. Kang et al. [70] observed for their peptide-human leukocyte antigen complexes of known structure, the number of hydrogen bonds and van der Waals contacts are directly proportional to the corresponding $\Delta H^{\#}$ values. We attribute the large unfavorable enthalpy for dissociation of the D17.4/IgE complex to D17.4/IgE electrostatic interactions. The change in entropy of activation $\left(\Delta S^{\#}\right)$ for dissociation of D17.4IgE complex is $-8.7 \pm 5.6 \mathrm{cal} \mathrm{mol}^{-1} \mathrm{~K}^{-1}$ and we attribute the negative unfavorable entropy change ( $\left.\Delta S^{\#}\right)$ to the requirement for re-condensation of ions onto the dissociated ligand, since the reverse process of association involving release of condensed ions involves a favorable entropic change [26].

The effect of salt on the D17.4 aptamer/IgE complex was studied by varying the $\mathrm{NaCl}$ concentration, and the activation parameters estimated are summarized in Table 1. The change in enthalpy of activation $\left(\Delta H^{\#}\right)$ was calculated as $15.4 \pm 1.9 \mathrm{kcal} \mathrm{mol}^{-1}$ at $50 \mathrm{mM} \mathrm{NaCl}$ and $1 \mathrm{mM}$ $\mathrm{MgCl}_{2}$, and $19.5 \pm 1.5 \mathrm{kcal} \mathrm{mol}^{-1}$ at $300 \mathrm{mM} \mathrm{NaCl}$ and $1 \mathrm{mM} \mathrm{MgCl}_{2}$. The change in enthalpy of activation was small with increasing $\mathrm{NaCl}$ concentration indicating that enthalpy of dissociation is not strongly influenced by the increasing ionic strength. Kosaganov et al. [71] previously 
studied the dissociation of peptide nucleic acid (PNA) - ssDNA complex at different $\mathrm{NaCl}$ concentration and observed that the dissociation enthalpy was independent of the ionic strength. The lack of dependence of dissociation enthalpy on ionic strength in their case was attributed to the fact that electrostatic interactions between DNA and PNA were compensated by the contribution of repulsive forces between different chains of the PNA.

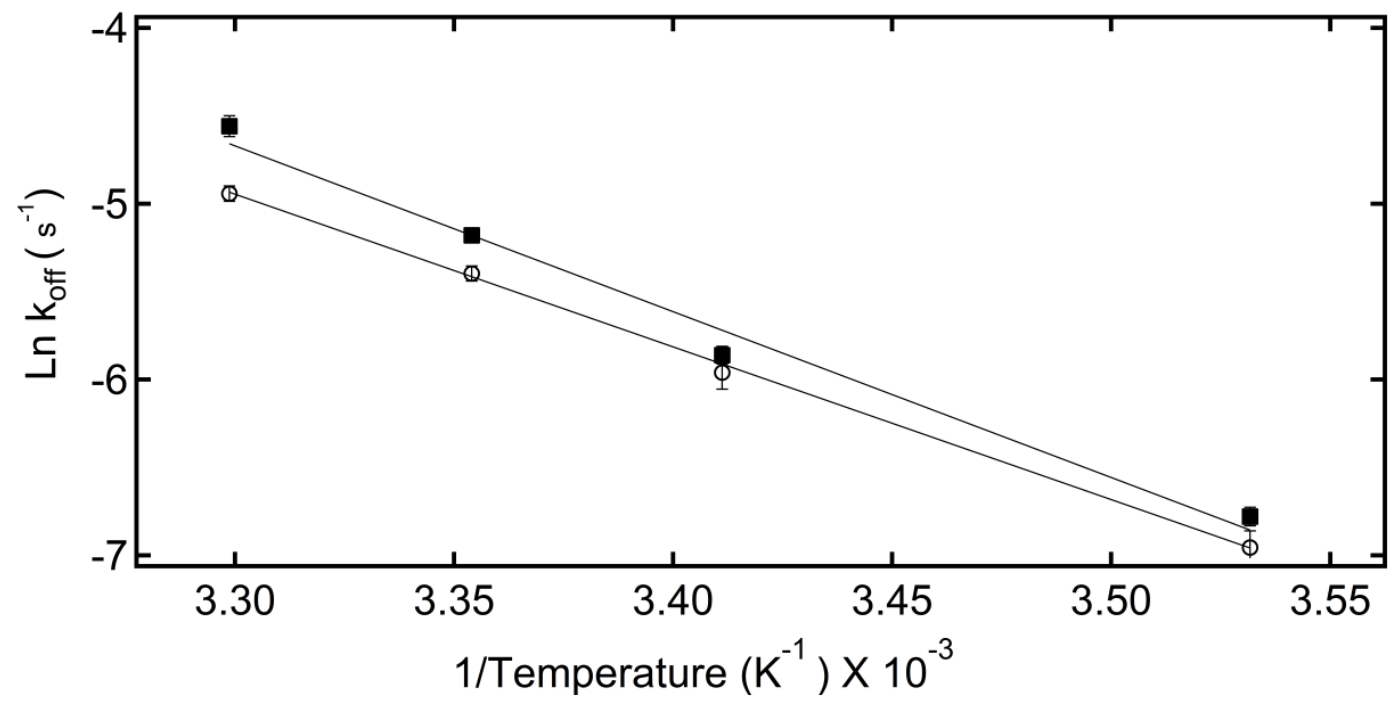

Fig. 12. Arrhenius plots for the dissociation of D17.4/IgE complex ( $\mathbf{m})$ and D17.4-C19A/IgE complex $(O)$ in binding buffer as a function of temperature. The activation parameters of D17.4C19A/IgE obtained from fitting these data are summarized in Table 2.

Our results show that the change in Gibbs free energy change of activation $\left(\Delta G^{\#}\right)$ with increasing $\mathrm{NaCl}$ was insignificant; $\Delta G^{\#}$ was calculated as $20.8 \pm 2.8 \mathrm{kcal} \mathrm{mol}^{-1}$ at $50 \mathrm{mM} \mathrm{NaCl}$ and $19.9 \pm 2.2 \mathrm{kcal} \mathrm{mol}^{-1}$ at $300 \mathrm{mM} \mathrm{NaCl}$ both containing $1 \mathrm{mM} \mathrm{MgCl}$. We have previously observed enthalpy/entropy compensation for the association of HyHEL-5 antibody with hen egg lysozyme (HEL), mutant R45K-HEL, California quail lysozyme (CQL) and bobwhite quail lysozyme (BWQL) using ITC studies [72]. A slope of unity in a plot of $\Delta H^{\#} v s \mathrm{~T} \Delta S^{\#}$ generally indicates entropy/enthalpy compensation effect. A possible entropy/enthalpy compensation 
effect for D17.4/IgE was ruled out for our system, since a plot of $\Delta H^{\#} v s \mathrm{~T} \Delta S^{\#}$ gave a slope of 1.22

The activation parameters for D17.4-C19A/IgE dissociation were obtained from the Arrhenius plot (Fig. 12) and are summarized in Table 2. The activation parameters for D17.4$\mathrm{C} 19 \mathrm{~A} / \mathrm{IgE}$ dissociation are $\Delta H^{\#}=17.1 \pm 0.3 \mathrm{kcal} \mathrm{mol}^{-1}$ and $\Delta S^{\#}=-12.0 \pm 1 \mathrm{cal} \mathrm{mol}^{-1} \mathrm{~K}^{-1}$ at 138 $\mathrm{mM} \mathrm{NaCl}$. Thus at $298 \mathrm{~K}$ there is an activation free energy barrier for the dissociation reaction of $\Delta G^{\#}=20.6 \pm 0.4 \mathrm{kcal} \mathrm{mol}^{-1}$. The measured activation parameters for the D17.4-C19A showed only small changes compared to the D17.4 aptamer as shown by the mutational $\Delta \Delta H^{\#}$ of $0.8 \pm 1.6 \mathrm{kcal} \mathrm{mol}^{-1}$ and $\Delta \Delta G^{\#}$ of $-0.1 \pm 2.3 \mathrm{kcal} \mathrm{mol}^{-1}$.

Table 2. Activation parameters for the dissociation of D17.4-C19A/IgE complex (at $138 \mathrm{mM}$ $\mathrm{NaCl}, 1 \mathrm{mM} \mathrm{MgCl}_{2}$ and $25^{\circ} \mathrm{C}$ ).

\begin{tabular}{|c|c|c|c|}
\hline & D17.4/IgE & $\begin{array}{c}\text { D17.4-C19A } \\
\text { mutant }\end{array}$ & Difference \\
\hline $\mathrm{k}_{\mathrm{off}}\left(\mathrm{s}^{-1}\right)$ & $(5.51 \pm 0.22) \times 10^{-3} \mathrm{~s}^{-1}$ & $(4.51 \pm 0.02) \times 10^{-3} \mathrm{~s}^{-1}$ & $(1.0 \pm 0.2) \times 10^{-3} \mathrm{~s}^{-1}$ \\
\hline $\begin{array}{c}\text { Activation } \\
\text { parameters }\end{array}$ & $18.5 \pm 1.6$ & $17.7 \pm 0.3$ & $\Delta \mathrm{E}_{\mathrm{a}}=0.8 \pm 1.6$ \\
\hline $\begin{array}{c}\mathrm{E}_{\mathrm{a}} \\
(\mathrm{kcal} / \mathrm{mol})\end{array}$ & $17.9 \pm 1.6$ & $17.1 \pm 0.3$ & $\Delta \Delta H^{\#}=0.8 \pm 1.6$ \\
\hline $\begin{array}{c}\Delta H^{\#} \\
(\mathrm{kcal} / \mathrm{mol})\end{array}$ & $-8.7 \pm 5.6$ & $-12.0 \pm 1.0$ & $\Delta \Delta S^{\#}=3.3 \pm 5.7$ \\
\hline $\begin{array}{c}\Delta S^{\#} \\
(\mathrm{cal} / \mathrm{mol} / \mathrm{K})\end{array}$ & $-2.5 \pm 1.6$ & $-3.5 \pm 0.3$ & $\mathrm{~T} \Delta \Delta S^{\#}=1.0 \pm 1.6$ \\
\hline $\begin{array}{c}\mathrm{T} \Delta S^{\#} \\
(\mathrm{kcal} / \mathrm{mol})\end{array}$ & $20.5 \pm 2.3$ & $20.6 \pm 0.4$ & $\Delta \Delta G^{\#}=-0.1 \pm 2.3$ \\
\hline $\begin{array}{c}\Delta G^{\#} \\
(\mathrm{kcal} / \mathrm{mol})\end{array}$ & \multicolumn{2}{|c|}{} \\
\hline
\end{tabular}


In conclusion, we present here what we believe to be the first measured activation energy parameters for an aptamer/protein system. For the D17.4 aptamer, we observed that both the change in activation enthalpy $\left(\Delta \Delta \mathrm{H}^{\#}\right)$ and entropy $\left(\Delta \Delta \mathrm{S}^{\#}\right)$ are minimal with increasing $\mathrm{NaCl}$ concentration. The dissociation of D17.4 aptamer/IgE complex showed a strong dependence on temperature and salt concentration and has been previously attributed to the conformational changes in the aptamer.

Application of such tools to drug development, especially for aptamers, is in its early stages. The present work is a fundamentally-oriented study, but illustrates some of the possibilities for drug characterization and development. In our study, we studied the dissociation kinetics of 3 different mutant D17.4 aptamers and identified a mutant (D17.4 C19A) whose $k_{\text {off }}$ is slower than original aptamer. A drug/aptamer with slower $\mathrm{k}_{\text {off }}$ has therapeutic advantage since drug residence time $\left(1 / \mathrm{k}_{\text {off }}\right)$ is often a better predictor of efficacy than binding affinity. Further the effect of salt on dissociation kinetics enabled to perform thermodynamic analysis of ion recondensation and to illustrate the electrostatic nature of D17.4 aptamer and IgE interaction.

Mutation studies showed that even for mutants with altered affinity for $\operatorname{IgE}$ but having same mfold-predicted stem-loop structure, the dissociation rate is similar, suggesting that D17.4 aptamer IgE recognition is mediated through the conserved loop structure as reported earlier. Interestingly, we found a mutant, D17.4-C19A with altered longer stem mfold structure that showed slower dissociation kinetics. The increasing $\mathrm{k}_{\text {off }}$ values at increasing salt concentration supports the notion that the $\mathrm{D} 17.4 / \mathrm{IgE}$ interaction is governed by electrostatic interactions.

Single-molecule dissociation kinetics showed greater kinetic complexity than was observed in the ensemble in-solution systems, potentially reflecting the IgE microheterogeneity, 
and/or directly signaling conformational heterogeneity of the aptamer [34, 50]. Due to photophysical constraints on operating conditions, the effect of $\mathrm{NaCl}$ and $\mathrm{MgCl}_{2}$ concentrations on kinetic heterogeneity could not be further pursued. These preliminary results establish, however, that with the use of labels with extended lifetimes or labels that do not undergo bleaching (inorganic semiconductor quantum dots, plasmonic particles, metal complexes) systems with faster desorption times could be studied using SMS to clarify sources of heterogeneity.

\section{Acknowledgements}

This work was supported by the Welch Foundation (E-1264) and NSF (CBET-1133965) to R.C.W. and by the Welch Foundation (C-1787) and NSF (CBET-1134417) to C.F.L. L.K. thanks the NSF for Graduate Research Fellowship 0940902.

\section{References}

[1] A.D. Ellington, J.W. Szostak, In vitro selection of RNA molecules that bind specific ligands, Nature, 346 (1990) 818-822.

[2] C. Tuerk, L. Gold, Systematic evolution of ligands by exponential enrichment: RNA ligands to bacteriophage T4 DNA polymerase, Science, 249 (1990) 505-510.

[3] S.A. Vinores, Pegaptanib in the treatment of wet, age-related macular degeneration, International journal of nanomedicine, 1 (2006) 263-268.

[4] P. Sundaram, H. Kurniawan, M.E. Byrne, J. Wower, Therapeutic RNA aptamers in clinical trials, European journal of pharmaceutical sciences : official journal of the European Federation for Pharmaceutical Sciences, 48 (2013) 259-271.

[5] J.C. Rohloff, A.D. Gelinas, T.C. Jarvis, U.A. Ochsner, D.J. Schneider, L. Gold, N. Janjic, Nucleic Acid Ligands With Protein-like Side Chains: Modified Aptamers and Their Use as Diagnostic and Therapeutic Agents, Mol Ther-Nucl Acids, 3 (2014).

[6] L.C. Bock, L.C. Griffin, J.A. Latham, E.H. Vermaas, J.J. Toole, Selection of Single-Stranded-DNA Molecules That Bind and Inhibit Human Thrombin, Nature, 355 (1992) 564-566.

[7] C.P. Rusconi, E. Scardino, J. Layzer, G.A. Pitoc, T.L. Ortel, D. Monroe, B.A. Sullenger, RNA aptamers as reversible antagonists of coagulation factor IXa, Nature, 419 (2002) 90-94.

[8] T. Hermann, D.J. Patel, Adaptive recognition by nucleic acid aptamers, Science, 287 (2000) 820-825.

[9] K. Thiel, Oligo oligarchy-the surprisingly small world of aptamers, Nature biotechnology, 22 (2004) 649-651.

[10] C.E. Tucker, L.S. Chen, M.B. Judkins, J.A. Farmer, S.C. Gill, D.W. Drolet, Detection and plasma pharmacokinetics of an anti-vascular endothelial growth factor oligonucleotide-aptamer (NX1838) in 
rhesus monkeys, Journal of chromatography. B, Biomedical sciences and applications, 732 (1999) 203212.

[11] W.E. Winter, N.S. Hardt, S. Fuhrman, Immunoglobulin E: importance in parasitic infections and hypersensitivity responses, Archives of pathology \& laboratory medicine, 124 (2000) 1382-1385.

[12] T.W. Wiegand, P.B. Williams, S.C. Dreskin, M.H. Jouvin, J.P. Kinet, D. Tasset, High-affinity oligonucleotide ligands to human IgE inhibit binding to Fc epsilon receptor I, Journal of immunology, 157 (1996) 221-230.

[13] K.H. Shu, J.D. Lian, Y.F. Yang, Y.S. Lu, J.Y. Wang, Serum IgE in primary glomerular diseases and its clinical significance, Nephron, 49 (1988) 24-28.

[14] R. Agarwal, D. Gupta, A.N. Aggarwal, A.K. Saxena, B. Saikia, A. Chakrabarti, S.K. Jindal, Clinical significance of decline in serum IgE levels in allergic bronchopulmonary aspergillosis, Respiratory medicine, 104 (2010) 204-210.

[15] D.Y.M. Leung, H.A. Sampson, J.W. Yunginger, A.W. Burks, L.C. Schneider, C.H. Wortel, F.M. Davis, J.D. Hyun, W.R. Shanahan, T.-P.A.S. Grp, Effect of Anti-IgE therapy in patients with peanut allergy, New Engl J Med, 348 (2003) 986-993.

[16] G. Gokulrangan, J.R. Unruh, D.F. Holub, B. Ingram, C.K. Johnson, G.S. Wilson, DNA aptamer-based bioanalysis of IgE by fluorescence anisotropy, Analytical chemistry, 77 (2005) 1963-1970.

[17] I. German, D.D. Buchanan, R.T. Kennedy, Aptamers as Ligands in Affinity Probe Capillary Electrophoresis, Analytical chemistry, 70 (1998) 4540-4545.

[18] J. Pollet, F. Delport, K.P. Janssen, K. Jans, G. Maes, H. Pfeiffer, M. Wevers, J. Lammertyn, Fiber optic SPR biosensing of DNA hybridization and DNA-protein interactions, Biosensors \& bioelectronics, 25 (2009) 864-869.

[19] J. Pollet, U. Strych, R.C. Willson, A peroxidase-active aptazyme as an isothermally amplifiable label in an aptazyme-linked oligonucleotide assay for low-picomolar IgE detection, The Analyst, 137 (2012) 5710.

[20] S. Kim, J. Lee, S.J. Lee, H.J. Lee, Ultra-sensitive detection of IgE using biofunctionalized nanoparticleenhanced SPR, Talanta, 81 (2010) 1755-1759.

[21] H.M. Lee, J. Kwon, J.S. Choi, K.H. Lee, S. Yang, S.M. Ko, J.K. Chung, S.Y. Cho, D. Kim, Rapid Detection of Norovirus from Fresh Lettuce Using Immunomagnetic Separation and a Quantum Dots Assay, J. Food Prot., 76 (2013) 707-711.

[22] Q. Peng, Z. Cao, C. Lau, M. Kai, J. Lu, Aptamer-barcode based immunoassay for the instantaneous derivatization chemiluminescence detection of IgE coupled to magnetic beads, Analyst, 136 (2011) 140147.

[23] D.T. Tran, V. Vermeeren, L. Grieten, S. Wenmackers, P. Wagner, J. Pollet, K.P. Janssen, L. Michiels, J. Lammertyn, Nanocrystalline diamond impedimetric aptasensor for the label-free detection of human IgE, Biosensors \& bioelectronics, 26 (2011) 2987-2993.

[24] M. Zuker, Mfold web server for nucleic acid folding and hybridization prediction, Nucleic acids research, 31 (2003) 3406-3415.

[25] A.D. Keefe, S. Pai, A. Ellington, Aptamers as therapeutics, Nature Reviews Drug Discovery, 9 (2010) 537-550.

[26] I. Kanakaraj, W.H. Chen, M. Poongavanam, S. Dhamane, L.J. Stagg, J.E. Ladbury, K. Kourentzi, U. Strych, R.C. Willson, Biophysical characterization of VEGF-aHt DNA aptamer interactions, Int J Biol Macromol, 57 (2013) 69-75.

[27] K. Kourentzi, M. Srinivasan, S.J. Smith-Gill, R.C. Willson, Conformational flexibility and kinetic complexity in antibody-antigen interactions, Journal of molecular recognition : JMR, 21 (2008) 114-121.

[28] K.A. Xavier, R.C. Willson, Association and dissociation kinetics of anti-hen egg lysozyme monoclonal antibodies HyHEL-5 and HyHEL-10, Biophysical journal, 74 (1998) 2036-2045. 
[29] A.S. Potty, K. Kourentzi, H. Fang, G.W. Jackson, X. Zhang, G.B. Legge, R.C. Willson, Biophysical characterization of DNA aptamer interactions with vascular endothelial growth factor, Biopolymers, 91 (2009) 145-156.

[30] A.S. Potty, K. Kourentzi, H. Fang, P. Schuck, R.C. Willson, Biophysical characterization of DNA and RNA aptamer interactions with hen egg lysozyme, Int J Biol Macromol, 48 (2011) 392-397.

[31] G. Bokinsky, L.G. Nivon, S. Liu, G. Chai, M. Hong, K.M. Weeks, X. Zhuang, Two distinct binding modes of a protein cofactor with its target RNA, J. Mol. Biol., 361 (2006) 771-784.

[32] J. Chen, A. Bremauntz, L. Kisley, B. Shuang, C.F. Landes, Super-Resolution mbPAINT for Optical Localization of Single-Stranded DNA, ACS Applied Materials \& Interfaces, 5 (2013) 9338-9343.

[33] L. Kisley, J. Chen, A.P. Mansur, S. Dominguez-Medina, E. Kulla, M.K. Kang, B. Shuang, K. Kourentzi, M.-V. Poongavanam, S. Dhamane, R.C. Willson, C.F. Landes, High ionic strength narrows the population of sites participating in protein ion-exchange adsorption: A single-molecule study, Journal of Chromatography A, 1343 (2014) 135-142.

[34] L. Kisley, J. Chen, A.P. Mansur, B. Shuang, K. Kourentzi, M.V. Poongavanam, W.H. Chen, S. Dhamane, R.C. Willson, C.F. Landes, Unified superresolution experiments and stochastic theory provide mechanistic insight into protein ion-exchange adsorptive separations, Proceedings of the National Academy of Sciences of the United States of America, 111 (2014) 2075-2080.

[35] J. Chen, N.K. Poddar, L.J. Tauzin, D. Cooper, A.B. Kolomeisky, C.F. Landes, Single-molecule FRET studies of HIV TAR-DNA hairpin unfolding dynamics, The journal of physical chemistry. B, 118 (2014) 12130-12139.

[36] W.E. Moerner, M. Orrit, Illuminating single molecules in condensed matter, Science, 283 (1999) 1670-1676.

[37] S. Weiss, Measuring conformational dynamics of biomolecules by single molecule fluorescence spectroscopy, Nat. Struct. Biol., 7 (2000) 724-729.

[38] X. Zhuang, Single-Molecule RNA Science, Ann. Rev. Biophys. Biomol. Struct., 34 (2005) 399-414.

[39] P.V. Cornish, D.N. Ermolenko, D.W. Staple, L. Hoang, R.P. Hickerson, H.F. Noller, T. Ha, Following movement of the L1 stalk between three functional states in single ribosomes, Proc. Natl. Acad. Sci. U. S. A., 106 (2009) 2571-2576.

[40] A.A. Deniz, T.A. Laurence, M. Dahan, D.S. Chemla, P.G. Schultz, S. Weiss, Ratiometric singlemolecule studies of freely diffusing biomolecules, Annu. Rev. Phys. Chem., 52 (2001) 233-253.

[41] T. Ha, Single-molecule fluorescence resonance energy transfer, Methods, 25 (2001) 78-86.

[42] P. Karam, A.A. Hariri, C.F. Calver, X.Y. Zhao, K.S. Schanze, G. Cosa, Interaction of Anionic Phenylene Ethynylene Polymers with Lipids: From Membrane Embedding to Liposome Fusion, Langmuir, 30 (2014) 10704-10711.

[43] M. Kastantin, B.B. Langdon, E.L. Chang, D.K. Schwartz, Single-molecule resolution of interfacial fibrinogen behavior: effects of oligomer populations and surface chemistry, Journal of the American Chemical Society, 133 (2011) 4975-4983.

[44] H.D. Kim, G.U. Nienhaus, T. Ha, J.W. Orr, J.R. Williamson, S. Chu, Mg2+-dependent conformational change of RNA studied by fluorescence correlation and FRET on immobilized single molecules, Proc. Natl. Acad. Sci. USA, 99 (2002) 4284-4289.

[45] M.P. Elenko, J.W. Szostak, A.M. van Oijen, Single-molecule imaging of an in vitro-evolved RNA aptamer reveals homogeneous ligand binding kinetics, Journal of the American Chemical Society, 131 (2009) 9866-9867.

[46] A.M. van Oijen, Single-molecule approaches to characterizing kinetics of biomolecular interactions, Current Opinion in Biotechnology, 22 (2011) 75-80.

[47] D. Canet, K. Doering, C.M. Dobson, Y. Dupont, High-Sensitivity Fluorescence Anisotropy Detection of Protein-Folding Events: Application to $\alpha$-Lactalbumin, Biophysical journal, 80 (2001) 1996-2003. 
[48] G.E. Cohn, J.C. Sutherland, Simultaneous measurement of circular dichroism and fluorescence polarization anisotropy., Proc. SPIE 4625, Clinical Diagnostic Systems: Technologies and Instrumentation, 4625 (2002) 126-136.

[49] J.E. Wampler, R.J. DeSa, Recording polarization of fluorescence spectrometer. Unique application of piezoelectric birefringence modulation, Analytical chemistry, 46 (1974) 563-567.

[50] L. Kisley, J. Chen, A.P. Mansur, S. Dominguez-Medina, E. Kulla, M.K. Kang, B. Shuang, K. Kourentzi, M.V. Poongavanam, S. Dhamane, R.C. Willson, C.F. Landes, High ionic strength narrows the population of sites participating in protein ion-exchange adsorption: a single-molecule study, Journal of chromatography. A, 1343 (2014) 135-142.

[51] L. Kisley, W.S. Chang, D. Cooper, A.P. Mansur, C.F. Landes, Extending single molecule fluorescence observation time by amplitude-modulated excitation, Methods Appl Fluoresc, 1 (2013) 037001-037001.

[52] E. Katilius, C. Flores, N.W. Woodbury, Exploring the sequence space of a DNA aptamer using microarrays, Nucleic acids research, 35 (2007) 7626-7635.

[53] R. McLachlan, A.P. Grigg, F.N. Cornell, R.A. Harris, R.K. Woodruff, Demonstration of monoclonal IgE by isoelectric focusing: first reported case of IgE myeloma in Australia, Clinical chemistry, 34 (1988) 2168-2171.

[54] B.J. Compton, J.S. Gerald, D.A. Lowe, R.P. Elander, Micro isoelectric point heterogeneity of a murine monoclonal antibody (L6) originating from cell cultivation conditions, Biotechnology Techniques, 3 (1989) 349-354.

[55] P.K. Tsai, M.W. Bruner, J.I. Irwin, C.C. Ip, C.N. Oliver, R.W. Nelson, D.B. Volkin, C.R. Middaugh, Origin of the isoelectric heterogeneity of monoclonal immunoglobulin h1B4, Pharmaceutical research, 10 (1993) 1580-1586.

[56] S. Hideshima, S. Kuroiwa, M. Kimura, S. Cheng, T. Osaka, Effect of the size of receptor in allergy detection using field effect transistor biosensor, Electrochimica Acta, 110 (2013) 146-151.

[57] B. Dhaliwal, D. Yuan, M.O.Y. Pang, A.J. Henry, K. Cain, A. Oxbrow, S.M. Fabiane, A.J. Beavil, J.M. McDonnell, H.J. Gould, B.J. Sutton, Crystal structure of IgE bound to its B-cell receptor CD23 reveals a mechanism of reciprocal allosteric inhibition with high affinity receptor FcRI, Proceedings of the National Academy of Sciences, 109 (2012) 12686-12691.

[58] T.M. Lohman, Kinetics of protein-nucleic acid interactions: use of salt effects to probe mechanisms of interaction, CRC critical reviews in biochemistry, 19 (1986) 191-245.

[59] M.T. Record, P.L. DeHaseth, T.M. Lohman, Interpretation of monovalent and divalent cation effects on the lac repressor-operator interaction, Biochemistry, 16 (1977) 4791-4796.

[60] Y. Jiang, J. Wang, X. Fang, C. Bai, Study of the effect of metal ion on the specific interaction between protein and aptamer by atomic force microscopy, Journal of nanoscience and nanotechnology, 4 (2004) 611-615.

[61] M. Antopolsky, N.O. Fischer, J.B.H. Tok, T.M. Tarasow, Massively Parallel Interrogation of Aptamer Sequence, Structure and Function, PLoS ONE, 3 (2008) e2720.

[62] J. Hoinka, E. Zotenko, A. Friedman, Z.E. Sauna, T.M. Przytycka, Identification of sequence-structure RNA binding motifs for SELEX-derived aptamers, Bioinformatics, 28 (2012) i215-i223.

[63] M. Platt, W. Rowe, J. Knowles, P.J. Day, D.B. Kell, Analysis of aptamer sequence activity relationships, Integrative Biology, 1 (2009) 116.

[64] L. Kisley, J. Chen, A.P. Mansur, B. Shuang, K. Kourentzi, M.V. Poongavanam, W.H. Chen, S. Dhamane, R.C. Willson, C.F. Landes, Unified superresolution experiments and stochastic theory provide mechanistic insight into protein ion-exchange adsorptive separations, Proceedings of the National Academy of Sciences, 111 (2014) 2075-2080.

[65] J. Nick Taylor, Q. Darugar, K. Kourentzi, R.C. Willson, C.F. Landes, Dynamics of an anti-VEGF DNA aptamer: A single-molecule study, Biochemical and Biophysical Research Communications, 373 (2008) 213-218. 
[66] R. Walder, M. Kastantin, D.K. Schwartz, High throughput single molecule tracking for analysis of rare populations and events, Analyst, 137 (2012) 2987-2996.

[67] A. Zielesny, From Curve Fitting to Machine Learning: An Illustrative Guide to Scientific Data Analysis and Computational Intelligence, Springer, Berlin, 2011.

[68] L. Kisley, J. Chen, A.P. Mansur, B. Shuang, K. Kourentzi, M.V. Poongavanam, W.H. Chen, S. Dhamane, R.C. Willson, C.F. Landes, Unified superresolution experiments and stochastic theory provide mechanistic insight into protein ion-exchange adsorptive separations, Proceedings of the National Academy of Sciences of the United States of America, (2014).

[69] K.A. Xavier, S.M. McDonald, J.A. McCammon, R.C. Willson, Association and dissociation kinetics of bobwhite quail lysozyme with monoclonal antibody HyHEL-5, Protein engineering, 12 (1999) 79-83.

[70] J. Kang, J.D. Auerbach, Thermodynamic characterization of dissociation rate variations of human leukocyte antigen and peptide complexes, Molecular Immunology, 46 (2009) 2873-2875.

[71] Y.N. Kosaganov, D.A. Stetsenko, E.N. Lubyako, N.P. Kvitko, Y.S. Lazurkin, P.E. Nielsen, Effect of Temperature and lonic Strength on the Dissociation Kinetics and Lifetime of PNA-DNA Triplexes, Biochemistry, 39 (2000) 11742-11747.

[72] K.A. Shick, K.A. Xavier, A. Rajpal, S.J. Smith-Gill, R.C. Willson, Association of the anti-hen egg lysozyme antibody HyHEL-5 with avian species variant and mutant lysozymes, Biochimica et Biophysica Acta (BBA) - Protein Structure and Molecular Enzymology, 1340 (1997) 205-214. 